Petar Puhmajer

Hrvatski restauratorski zavod, Zagreb

Krasanka Majer Jurišić

Hrvatski restauratorski zavod, Zagreb

\title{
Stara gradska vijećnica u Rijeci: povijest sjedišta gradske vlasti od najranijih zapisa do 19. stoljeća
}

\author{
Izvorni znanstveni rad - Original scientific paper \\ Primljen - Received 16. 7. 2018. \\ UDK 72.034 .7 (497.5Rijeka)"15/17" \\ DOI 10.31664/ripu.2018.42.05
}

\begin{abstract}
Sažetak
U članku se tumače arhivski izvori o povijesti zgrade na Koblerovu trgu u Rijeci koja je od 16. do 19. stoljeća služila kao gradska vijećnica. Od prvotne stambene kuće, prenamijenjene za vijećnicu 1532. godine, zgrada je doživjela brojne promjene. Najvažnija je bila ona iz 1740.-1745. prema projektu arhitekta Antonija de Vernede, kada je nadograden drugi kat, pripojena susjedna kuća, pročelja u cijelosti preoblikovana u baroknom stilu, te je kao takva, uz manje preinake, zgrada ostala sačuvana do danas. Nakon toga oštećena je u potresu 1750. te je po-
\end{abstract}

novno obnovljena u nekoliko navrata. U kasnom 18. stoljeću nalazimo da se njezine prostorije koriste za razna društvena i javna događanja. Kao vijećnica služila je sve do 1833. godine, a zatim se gradska uprava preselila u bivši augustinski samostan te je zgrada prenamijenjena u trgovačke i stambene svrhe. S položajem na križanju glavnih ulica $i$ središnjega trga, stara vijećnica ima i urbanističko značenje. U članku se takoder donose rezultati konzervatorskih istraživanja kojima su razlučene faze njezina građevnog razvoja.

Ključne riječi: arhitektura, 16. stoljeće, 18. stoljeće, barokna arhitektura, Rijeka, gradska vijećnica, loža, Antonio de Verneda, građevni razvoj

Na sjevernoj strani Koblerova trga u Rijeci, nekadašnjega glavnog gradskog trga, Platea comunis, a poslije Piazza delle Erbe i Piazza dei Frutti, smještena je dvokatnica (sl. 1) koja je tristotinjak godina služila kao gradska vijećnica, odnosno općinska palača. ${ }^{1}$ Tu su se održavale sjednice gradskog vijeća, rješavala imovinsko-pravna pitanja i djelovao javni sud. Zgrada se nazivala Palazzo, što je skraćeno od Palazzo Pubblico, uobičajeni naziv za gradsku vijećnicu, pa se ona kolokvijalno nazivala i Palazzo di Fiume, Palazzo del Comune di Fiume, odnosno poslije na hrvatskom Palac Komuna riečkoga ili samo Palac Komuna, o čemu svjedoče arhivski dokumenti od 16. do početka 20. stoljeća.

Unatoč mijenama riječkoga Starog grada, zgrada je do danas sačuvala izvanredan urbanistički smještaj. Načelno pravokutnog tlocrta, položena je u smjeru sjever - jug na sjecištu četiriju ulica, i to tako da je usko glavno pročelje s dvjema prozorskim osima okrenuto ka Koblerovu trgu, ali je istodobno u regulacijskoj liniji kuća na sjevernoj strani
Užarske, nekad glavne trgovačke arterije Starog grada. Duža pročelja orijentirana su prema ulici Stara vrata, s jednostavnim nizovima prozorskih osi, te Medulićevoj, gdje se uočava nekoliko rizalitnih prigradnji uz glavni korpus. Zgrada je, dakle, s triju strana omeđena javnim prostorom ulice, a tek sa sjeverne spojena sa susjednim kućama pa tako čini tanak južni završetak vrlo izdužena gradskog bloka.

Obnova pročelja zgrade 2017.-2018. bila je povod za arhivska i konzervatorska istraživanja, ${ }^{2}$ utvrđivanje povijesne kronologije te slijeda građevinskih zahvata, koji su u višestoljetnoj povijesti građevine bili izuzetno brojni.

\section{Vijećnica i loža u 15. stoljeću}

U srednjovjekovnom razdoblju Rijeka je imala statute i privilegije kojima su se donosili zakoni i uređivalo upravljanje gradom. Za potrebe funkcioniranja uprave i suda morala je 


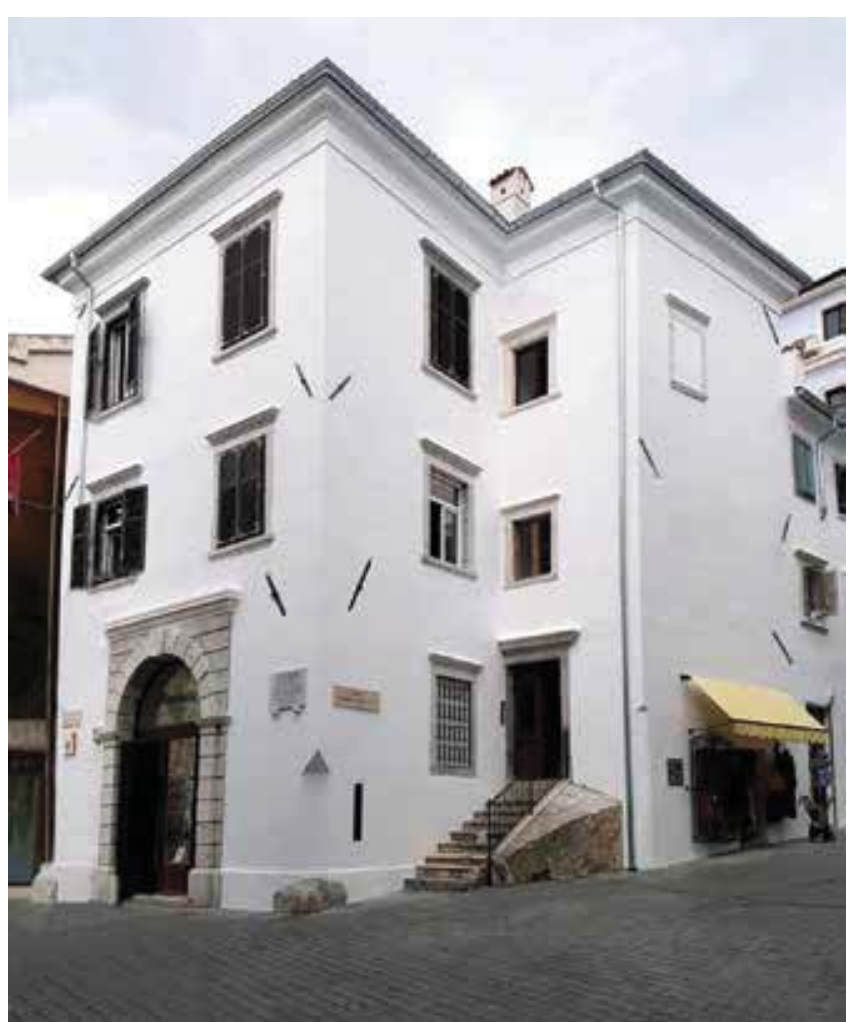

1. Stara gradska vijećnica u Rijeci, pogled s jugoistoka, 2018. Old Town Hall in Rijeka, southeast view, 2018

postojati građevina unutar gradskih zidina ili prostor određen za takvu funkciju, no nije poznato je li već tada postojala i namjenski građena zgrada. $U$ to je vrijeme najčešće u tu svrhu služila loža, ${ }^{3}$ a u pojedinim većim centrima grade se zasebne veće građevine koje su imale dvoranu za vijećanje, urede, a u nekim slučajevima i stan upravitelja, odnosno gradonačelnika.

Prema notarskim zapisima zna se da su u Rijeci još u 15. stoljeću suci poslove obavljali u loži, a da su se sjednice vijeća tada održavale u staroj crkvi sv. Vida, crkvi Uznesenja Marijina, u kaštelu, loži ili pak u nekoj privatnoj kući. ${ }^{4}$ Riječka gradska loža vjerojatno je bila manja prizemna građevina, rastvorena lukovima ili pak stupovima s gređem, a u njoj je uobičajeno bio sudački stol i kamene klupe. Prema odluci vijeća iz 1444. u gradu su vrijedile jedino presude izrečene upravo u loži, dok se presude donesene drugdje nisu smatrale važećima. ${ }^{5}$ Osim toga, u loži su se, osim suđenja, vodili i drugi javni poslovi, objavljivale odluke, sklapali sporazumi i ugovori. Smatra se da je loža još u 15. stoljeću bila na prostoru gradskog trga (platea comunis), a da je u drugoj polovini 16. stoljeća preseljena izvan gradskih zidina, ispred južne kule gradskih vrata. ${ }^{6}$ Njezin položaj izvan grada vidljiv je na prikazu Rijeke iz 1649. godine (vidi sl. 4) gdje je i označena riječju Loza. Ta je nova loža srušena 1728. godine. ${ }^{7}$

$\mathrm{Na}$ imaginarnom crtežu središnjega gradskog trga u Rijeci, nastalom oko 1913. godine, koji prikazuje pretpostavljenu situaciju u 16. stoljeću, Riccardo Gigante smješta ložu na glavni gradski trg, točnije na njegovu zapadnu stranu (sl. 2), a vijećnicu na sjevernu stranu, gdje se i danas nalazi. ${ }^{8}$ Taj je

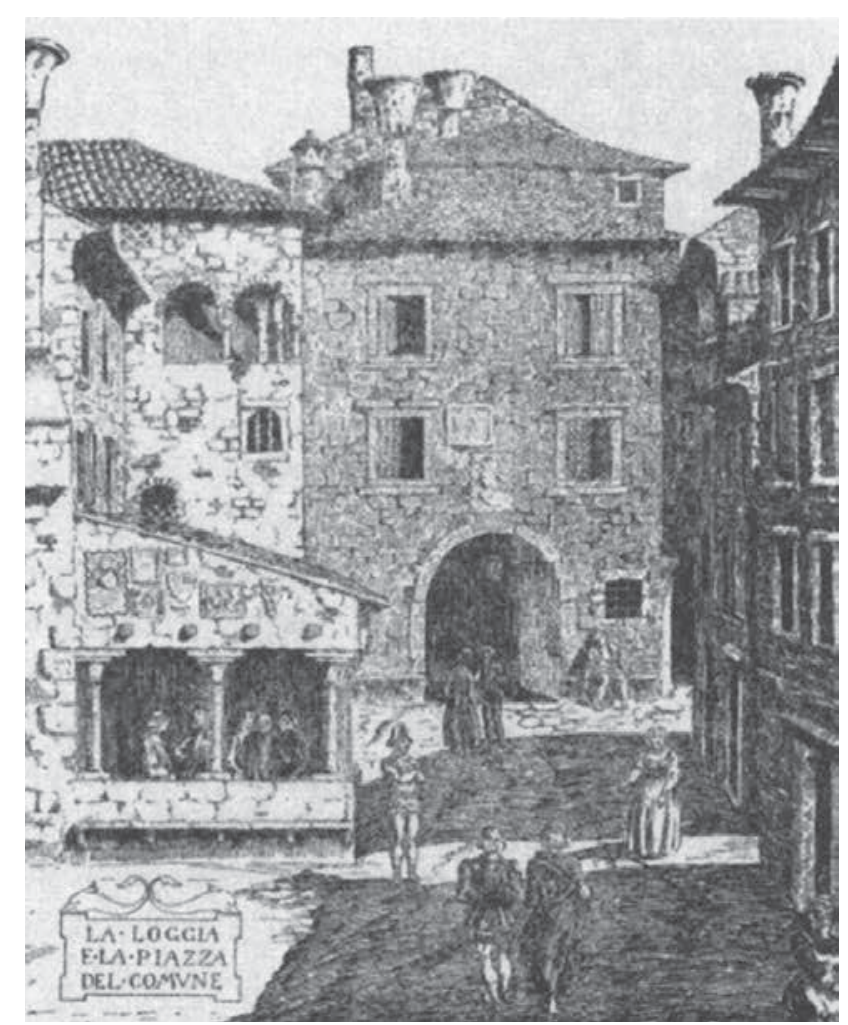

2. Riccardo Gigante, prikaz gradske vijećnice i lože na imaginarnom crtežu Koblerova trga u 16. st., objavljen u radu Silvina Gigantea Fiume nel Quattrocento (1913.)

Town Hall and Loggia in an imaginary drawing of Kobler Square in the 16th century, by Riccardo Gigante, published in Fiume nel Quattrocento by Silvino Gigante (1913)

crtež neko vrijeme smatran autentičnim prikazom izgleda trga u tom razdoblju, no već prema samoj vijećnici, koja je prikazana u visini dva kata, a vidjet ćemo da je drugi izgrađen tek u prvoj polovini 18. stoljeća, može se zaključiti da crtež nije utemeljen na vjerodostojnim povijesnim podacima.

\section{Izgradnja vijećnice i njezini prikazi u 16. i 17. stoljeću}

Vijećnica se u Rijeci najranije spominje 1525. godine kao palatio Comunis, kod gradskog notara Ravize. ${ }^{9}$ Naime, potreba za definiranjem prostora za održavanje sjednica gradskog vijeća pojavila se upravo $\mathrm{u}$ to vrijeme donošenjem novog statuta sastavljena 1527. i odobrena 1530. godine, prema odluci cara Ferdinanda Habsburškog, koji je važio za područje Rijeke. ${ }^{10}$ Novim statutom znatno je povećan broj gradskih vijećnika ${ }^{11}$ u odnosu na ranije razdoblje, kada je na pojedinoj sjednici bilo najviše šesnaest vijećnika. ${ }^{12}$ Potreba za većim prostorom u kojem je moguće održavati sjednice i okupiti potreban broj članova bila je zapravo razlog da se unutar gradske jezgre u jednoj građevini odredi stalan, opremljen i dovoljno velik prostor. U tu je svrhu gradski magistrat kupio 1532. godine kuću od riječkih augustinaca te ju dao urediti za vijećnicu. ${ }^{13}$ Kuću su augustinci stekli još 1484 . godine ${ }^{14}$ kao zakladu kapetana Baldassarea de Durra. ${ }^{15}$ Prema nekim, zasad nepotvrđenim podacima, ta je kuća navodno bila katnica, s dvoranom za sjednice vijeća do koje se uspinjalo vanjskim kamenim stubištem. ${ }^{16} \mathrm{U}$ prizemlju se nalazio svođeni atrij, ${ }^{17}$ koji je jedno 

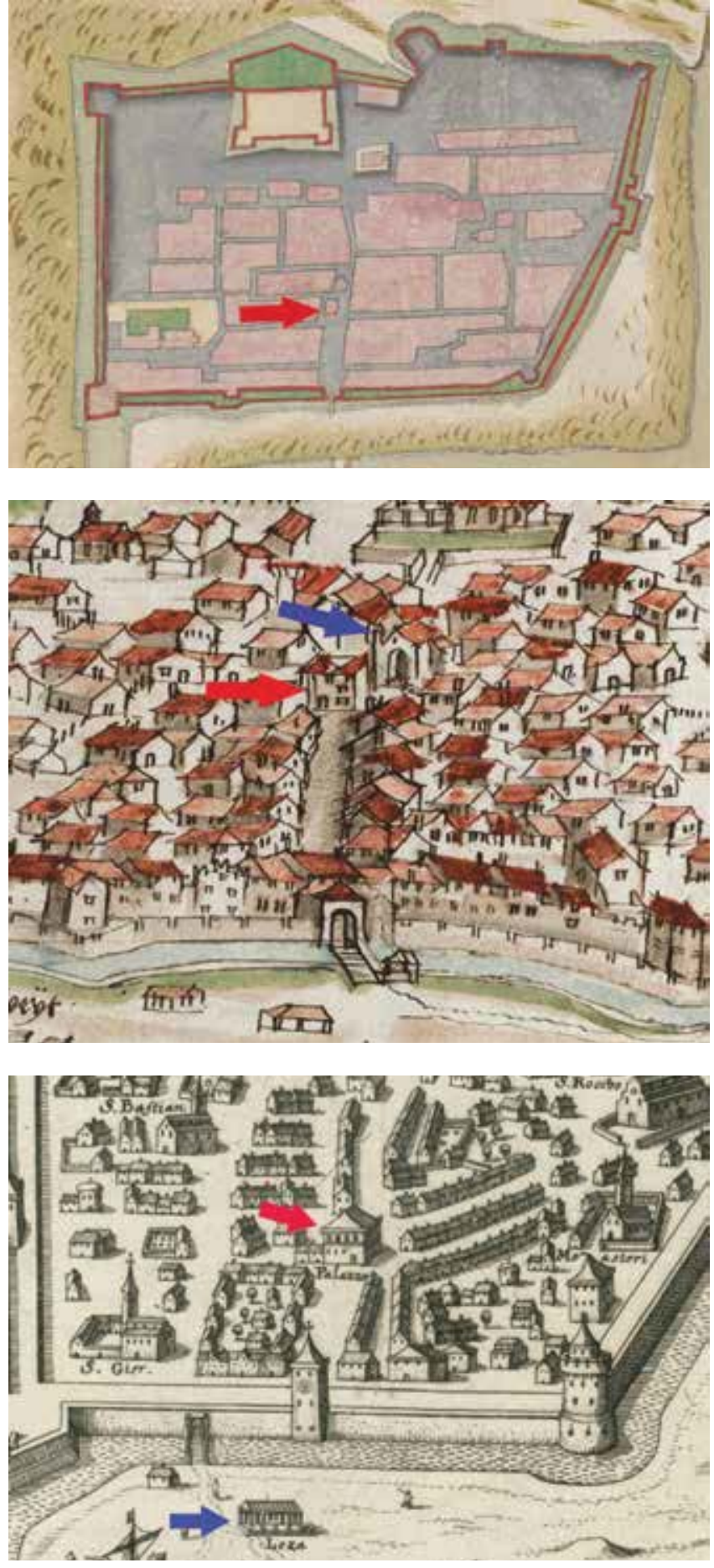

3. Plan Rijeke iz 16. st. (ÖNB, Cod. 8607, fol. 3r, Fiume) s označenom lokacijom kasnije vijećnice

Map of 16th-century Rijeka (ÖNB, Cod. 8607, fol. 3r, Fiume) with indicated location of the later town hall

4. Zgrada koja bi mogla biti gradska vijećnica (crvena strelica) te građevina s lučnim otvorom, vjerojatno kapela (plava strelica), na prikazu Rijeke Ivana Klobučarića iz 1559.

Possibly the town hall (red arrow) and a building with an arch, likely a chapel (blue arrow) in a drawing of Rijeka by Ivan Klobučarić, 1559

5. Palazzo (crvena strelica) i Loza, loža van gradskih zidina (plava strelica), na grafici Rijeke iz 1649. g. Matthäusa Meriana

Palazzo (red arrow) and Loza, loggia outside the town walls (blue arrow), in a view of Rijeka by Matthäus Merian, 1649 vrijeme mogao služiti za javne potrebe, ali i trgovinu, što je možda bila njegova namjena nakon gradnje nove lože izvan zidina u drugoj polovini 16. stoljeća. Na glavno, južno, pročelje postavljena je kamena ploča s prikazom okrunjenoga kraljevskog orla ispranih boja i štitom na kojem su bila slova F.I. označavajući ime cara Ferdinanda I., dok je pod orlom pisalo A.F.-I.O.V. (moguće Austria felix in orbe vivat). U donjem dijelu ploče stajao je epigraf: Comunitas fieri fecit tempore Dom: Francisci Barbo Capitanei et Judicum Antonii Rossovich et Joannis Speciarich anno 1560, što se u prijevodu čita: »Općina dade učiniti u vrijeme gospodina kapetana Franje Barba i sudaca Antuna Rusovića i Ivana Specijarića godine 1560.«18

Na dosad nepoznatom planu Rijeke iz sredine 16. stoljeća, koji se čuva u Österreichische Nationalbibliothek u Beču (sl. 3), ${ }^{19}$ nalazimo jednu građevinu pravokutnog tlocrta, položenu u smjeru sjever - jug, smještenu na sjevernom dijelu Koblerova trga i u regulacijskoj liniji Užarske ulice, po čemu zaključujemo da je riječ o današnjem položaju vijećnice. Iza nje, prema sjeveru, neka je građevina koja ima nacrtanu polukružnu apsidu, pa pretpostavljamo da je riječ o crkvi. Klobučarićev prikaz Rijeke iz 1559. godine ${ }^{20}$ sugerira istu situaciju (sl. 4), gdje se vidi zgrada okrenuta prema trgu, a iza nje građevina $s$ velikim lučnim portalom i tornjićem, vjerojatno preslicom za zvono, koja podsjeća na crkvu. Merianova grafika Rijeke iz 1649. godine (sl. 5) $)^{21}$ na istom mjestu prikazuje veću zgradu, u prizemlju rastvorenu širokim lučnim otvorom i trima prozorima, a na katu sa čak četiri prozora, koja je označena rječju Palazzo, pa je neupitno da je riječ o vijećnici. Vijećnica je dakle postojala već u 17. stoljeću na istom mjestu, a ono odgovara današnjem. Budući da je vrlo slična situacija i na ranijim planovima, možemo s velikom vjerojatnošću reći da se ona tamo nalazila još u 16. stoljeću.

U vremenu od njezine izgradnje pa sve do kasnijih preuređenja i dogradnji, prostori riječke vijećnice odgovarali su potrebama funkcioniranja gradske uprave, a s obzirom na njezino značenje, možemo pretpostaviti da je bila primjereno uređena. O tome nam daje naslutiti i J. W. Valvasor u 17. stoljeću, koji, opisujući procesiju Kastavaca prema Trsatu, bilježi da su zidovi u dvorani za vijećanje obloženi tapetama, a da se na podovima nalaze prostirke. ${ }^{22}$

\section{Obnova i nadogradnja prema projektu Antonija de Vernede 1740.-1745.}

S vremenom su potrebe za dodatnim prostorom u vijećnici bile sve veće ${ }^{23}$ i početkom 18 . stoljeća gradska je uprava razmatrala kupnju kuće nekog liječnika Perija ${ }^{24}$ kako bi se u njoj uredili prostori za vijećnicu, no do toga nikad nije došlo. Problem je ostao i idućih desetljeća, sve do 1740., kada se gradsko vijeće odlučilo na obnovu i dogradnju postojeće zgrade.

Angažiran je gradski inženjer Antonio de Verneda (1693.1774.), arhitekt kojemu su povjereni svi veći javni i infrastrukturni projekti, kao i privatne i crkvene gradnje tog vremena $\mathrm{u}$ Rijeci, ${ }^{25}$ a dobio je zadatak preurediti vijećnicu i dograditi drugi kat. Na prvom je katu trebalo smjestiti sud, ured i arhiv, a na drugom dvoranu za sjednice i ured gradskog kancelara. ${ }^{26}$ Nekoliko zapisa sjednica gradskog vijeća govori nam o tijeku projekta. 
Dana 12. ožujka 1740. sjednica je održana u staroj jednokatnici, kao i u travnju iste godine, ali je najavljen početak radova pred zimu jer je zgrada bila u vrlo lošem stanju i oštećena krova. Predloženo je podizanje drugoga kata nad tadašnjom dvoranom za vijećanje, koja bi se u budućnosti koristila za sudske poslove i arhiv, a na novom bi katu bio osiguran prostor za vijeće. $U$ tu svrhu bilo je nužno u međuvremenu riješiti najam prostora za rad gradske uprave tijekom trajanja radova. ${ }^{27} \mathrm{U}$ srpnju se od inženjera Vernede traži da se iznova pregledaju potrebni troškovi, ${ }^{28}$ dok istovremeno članovi gradskog vijeća negoduju zbog nemogućnosti održavanja sjednica u prikladnom prostoru. ${ }^{29}$ Cijena radova očigledno je bila visoka jer se u kolovozu postavilo pitanje potrebe podizanja novoga kata, odnosno predlaže se da se izvedu samo najnužniji radovi $\mathrm{i}$ »uljepšavanje« dvorane, te da se dodatni prostor dobije smanjenjem dvorane, unutar koje je trebalo smjestiti stube za prostoriju arhiva. ${ }^{30} \mathrm{Od}$ lučeno je da će se sjednice održavati u kaštelu, a gradski uredi preseliti u privatne kuće. ${ }^{31}$ Traženo je da se požuri s radovima, barem onima na uređenju gradskih ureda i arhiva kako bi se izbjegla dodatna davanja za najam i za to su zaduženi gradski suci. Oni su se također morali pobrinuti da se za nastavak radova na vijećnici koristi dobra, odležala drvna građa. ${ }^{32}$

U rujnu $1742 .{ }^{33}$ gradski kapetan zahtijeva da se radovi što prije dovrše, što zbog potrebe prostora za održavanje sjednica, što zbog pohrane spisa. Također navodi da je zgrada zasad samo ožbukana, a trebala bi biti na ures grada pa je odobren dodatni iznos od 500 dukata da se završi obnova. To ipak nije bilo dostatno jer se i iduće proljeće zadužuju gradski suci da iznađu način pokrivanja troškova za dovršetak radova te za isplatu poslova koje je već izveo neki Galop (vjerojatno graditelj, op. a.). ${ }^{34}$

Još je na početku radova bilo odlučeno je da se pročelje zgrade ukrasi natpisima, a dva prozora na glavnom pročelju osvijetle bakljama, ${ }^{35}$ pa se može pretpostaviti da su u vrijeme Vernedine obnove postavljene i dvije kamene ploče koje spominju kasniji zapisi. Jedna je ploča vjerojatno bila ona $s$ kraljevskim orlom i spomenom uređenja zgrade u 16. stoljeću, o kojoj je bilo riječi u prethodnom odlomku, a druga bi mogla biti ona koju opisuje grof Vincenzo Batthyany 1805. godine navodeći da su na pročelju bile dvije topovske kugle zajedno s natpisom Haec nobis quondam Gallia poma dedit, kao spomenom na francusku opsadu grada 1702 . godine. ${ }^{36}$ Radovi na vijećnici potrajali su gotovo pet godina, pa se konačno, od početka 1745., gradske sjednice redovito održavaju u velikoj dvorani, in sala superiori Palatii Communis Fluminis, ${ }^{37}$ zgrade na Koblerovu trgu.

\section{Obnove i adaptacije nakon potresa u drugoj polovini 18. stoljeća}

Vrlo brzo nakon toga Rijeku je 1750. pogodilo nekoliko jakih potresa u kojima je stradao velik dio grada, privatne kuće, crkve i samostani, te gradska vijećnica. ${ }^{38}$ Naime, u svibnju 1751. zapisano je da je sjednica gradskog vijeća održana izvan gradskih zidina, u kući Giacoma Zanchija. ${ }^{39}$ Razlog tome je što je zgrada bila oštećena u potresu, kao i toranj, s kojeg je skinuto zvono kojim se najavljivao početak sjednica. O popravcima zasad nismo našli podatke, ali je izgledno da su uslijedili neki radovi, na što ukazuju i konzervatorska istraživanja (vidi niže u tekstu). No oni su tih godina bili manjeg opsega, vjerojatno kako bi se zgrada što prije ponovo stavila u funkciju.

Već šezdesetih je opet u funkciji jer se tražilo da dvorana za sjednice vijeća, koja nije imala zidnih slika, bude opremljena portretima i obiteljskim grbovima plemića, a u jednom dijelu bude prostor rezerviran za natpise. ${ }^{40}$ Dvorana je morala biti reprezentativna i dobro uređena jer su se u njoj tih godina, osim gradskih sjednica, redovito održavali i javni plesovi. ${ }^{41}$

Sedamdesetih godina uslijedila je još jedna obnova, o kojoj zasad ne nalazimo podatke, osim što je na jednoj sjednici gradskog vijeća iz 1780. zaključeno da je zgrada uređena prema nekadašnjem izgledu iz vremena kada je bila u vlasništvu kapetana De Dura. ${ }^{42}$ Moguće da su napravljene nove dogradnje uz istočno pročelje, a svakako je uređeno i glavno stubište, o čemu će još biti riječi. Povodom za obnovu bila je odluka gradskog vijeća od 16. studenog 1779 . godine da se u prizemlju vijećnice jedna prostorija uredi za plemićki klub, Casino patriziale, a jedna za potrebe trgovačke burze, Borsa mercantile..$^{43} \mathrm{O}$ tome govori ilustrativan opis u zapisnicima gradskog magistrata: »Preuzvišeni i presvijetli gospodin guverner i civilni kapetan, uvijek zauzet kako oko koristi tako i oko časti za ovaj grad, uočavajući da ovome gradu nedostaju stanovite korisne ustanove koje imaju gotovo svi trgovački gradovi, a to su posebice Trgovačka burza, odnosno mjesto na kojemu bi se trgovci imali sastajati i gdje bi se raspravljale njihove građanske razmirice, kao i Kasino, odnosno prikladno javno mjesto gdje bi časniji ljudi, kako domaći, tako i došljaci, sastajući se uvečer provodili prve sate noći u igri ili u razgovoru, prema običaju drugih trgovačkih gradova u Italiji, Njegova rečena Uzvišenost vjeruje da rečena dva objekta, kao ona koja nemalo doprinose privlačenju stranih trgovaca ovamo, ali i u određenoj mjeri unapređuju kvalitetu života u ovome gradu, ovo Vijeće treba svom usrdnošću tražiti i prigrliti. « ${ }^{44}$

Gradska je vijećnica izabrana za smještaj tih novih sadržaja prije svega zbog smanjenja potrebnih troškova, ali i da oni budu pristupačni, u središtu grada i u međusobnoj blizini: „Glavna bi se dvorana, u kojoj se sada održavaju sjednice vijeća, ostavila da i dalje služi istoj svrsi, a uz to bi u njoj kao sudnici gospoda sudci održavala i redovita ročišta. Susjedna bi prostorija, takozvana segreteria, bila namijenjena arhivu vijeća i suda, a napravila bi se i vrata za prolaz prema drugoj, nešto manjoj prostoriji, u kojoj se bez poteškoća mogu smjestiti četiri osobe za pisaćim stolovima, i tu bi se uspostavila općinska kancelarija; druga, slična prostorija, koja se nalazi uza stube prema gornjem katu i blizu gore navedene glavne dvorane, odnosno sudnice, bila bi namijenjena upotrebi odvjetnika i stranaka na sudu. Nadalje, prostorija koja se nalazi niže, a u kojoj se sada održavaju ročišta i u kojoj je sudski arhiv, spojila bi se rušenjem zida sa susjednom prostorijom, a sljedeće bi se dvije prostorije također rušenjem pregradnoga zida međusobno spojile u jednu sličnu prethodnoj. Obje bi se prostorije koristile danju kao Burza, a noću kao Kasino. Nadalje, od kuhinje, prostorije za loženje i sadašnjega zapovjedništva gradskih postrojbi načinila bi se spremišta za potrepštine koje pripadaju Gradu, osobito za one koje služe gašenju požara, s time da bi se sačuvao jedan mali prostor koji bi bio namijenjen gradskoj straži. Naposljetku, u kućici 


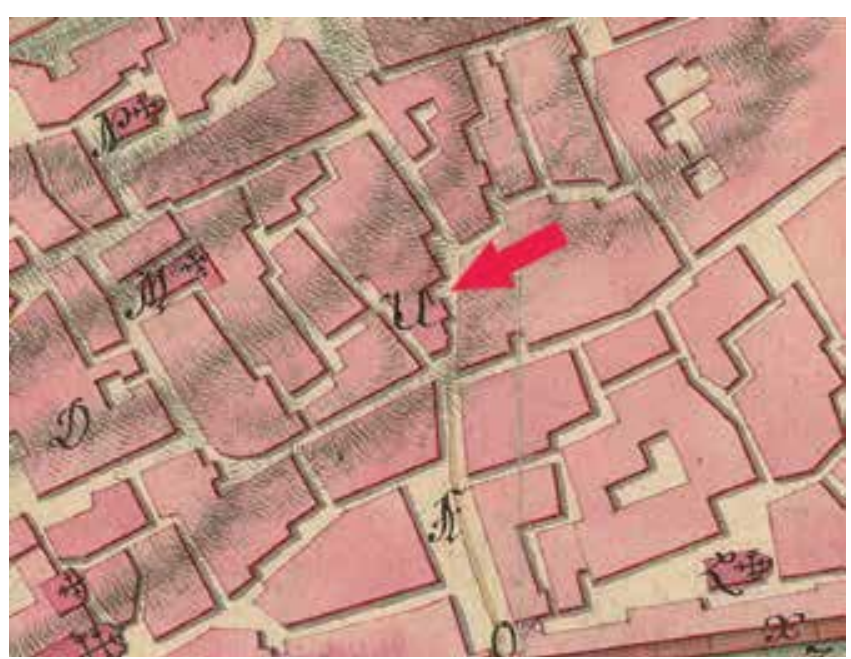

6. Detalj gradske vijećnice označene slovom U na planu Rijeke koji je izradio tzv. Hauptmann von Benko, 1766.

Town Hall marked with a letter $U$ on a map of Rijeka made by "Hauptmann von Benko", 1766

koja se nalazi bočno odmah uz palaču smjestilo bi se zapovjedništvo gradske vojske ove općine. « ${ }^{45}$

Ti su radovi doista bili izvedeni. Za upravitelja novoosnovanog kasina imenovan je Matteo Paravich, a za poslove vođenja kasina je 1780. Giovanniju Forestiju iz gradske blagajne bilo isplaćeno 300 forinti. ${ }^{46} \mathrm{U}$ kontekstu tog uređenja zanimljiv je opis zgrade Josipa Završnika s početka 19. stoljeća, koji kaže da je zgrada obnovljena u njegovo vrijeme, te uz konstataciju da je lijepa žali što ima tako tijesno stubište »na puž«, a među ostalim, spominje malu kavanu i biljar »u stražnjem dijelu «, gdje zalaze plemići. ${ }^{47}$ Zgrada je u to doba zabilježena na nekoliko planova Rijeke, većinom samo kao dio nepravilne gradske inzule unutar guste urbane strukture Staroga grada, na kojemu se vidi i stubišni blok uz istočno pročelje, primjerice na Benkovu planu Rijeke iz 1766. (sl. $6)^{48}$ ili pak Candidovu planu iz 1814. godine. ${ }^{49}$

\section{Preseljenje gradske uprave i sudbina zgrade tijekom 19. i 20. stoljeća}

U prvoj četvrtini 19. stoljeća gradska je uprava zbog povećanih administrativnih potreba javnog ureda, što je dakako bilo povezano i s naglim porastom broja stanovnika Rijeke, počela razmatrati mogućnosti iznalaska dodatnih prostora. Jedna je opcija bilo preseljenje u drugu zgradu i već se 1820 . željelo otkupiti sklop bivšeg augustinskog samostana, što je odgođeno zbog promjene vlasti 1822. godine. Kao druga opcija uzeto je u obzir proširenje postojeće zgrade. Godine 1832. zatražena je izrada plana za uređenje susjednih, sjevernih kuća Fumulo i Fanello za potrebe rada gradske uprave te njihovo pripajanje uza zgradu vijećnice. Gradski inženjer Adam Olf izradio je projekt (sl. 7a, b) s procjenom troško-

7a. Projekt za adaptaciju zgrade i pripojenje susjednih kuća, tlocrti prizemlja prvog i drugog kata, Adam Olf, 1832.

Plan for the renovation of the building and adjoining the neighbouring houses, ground plans of the first and second floors, Adam Olf, 1832

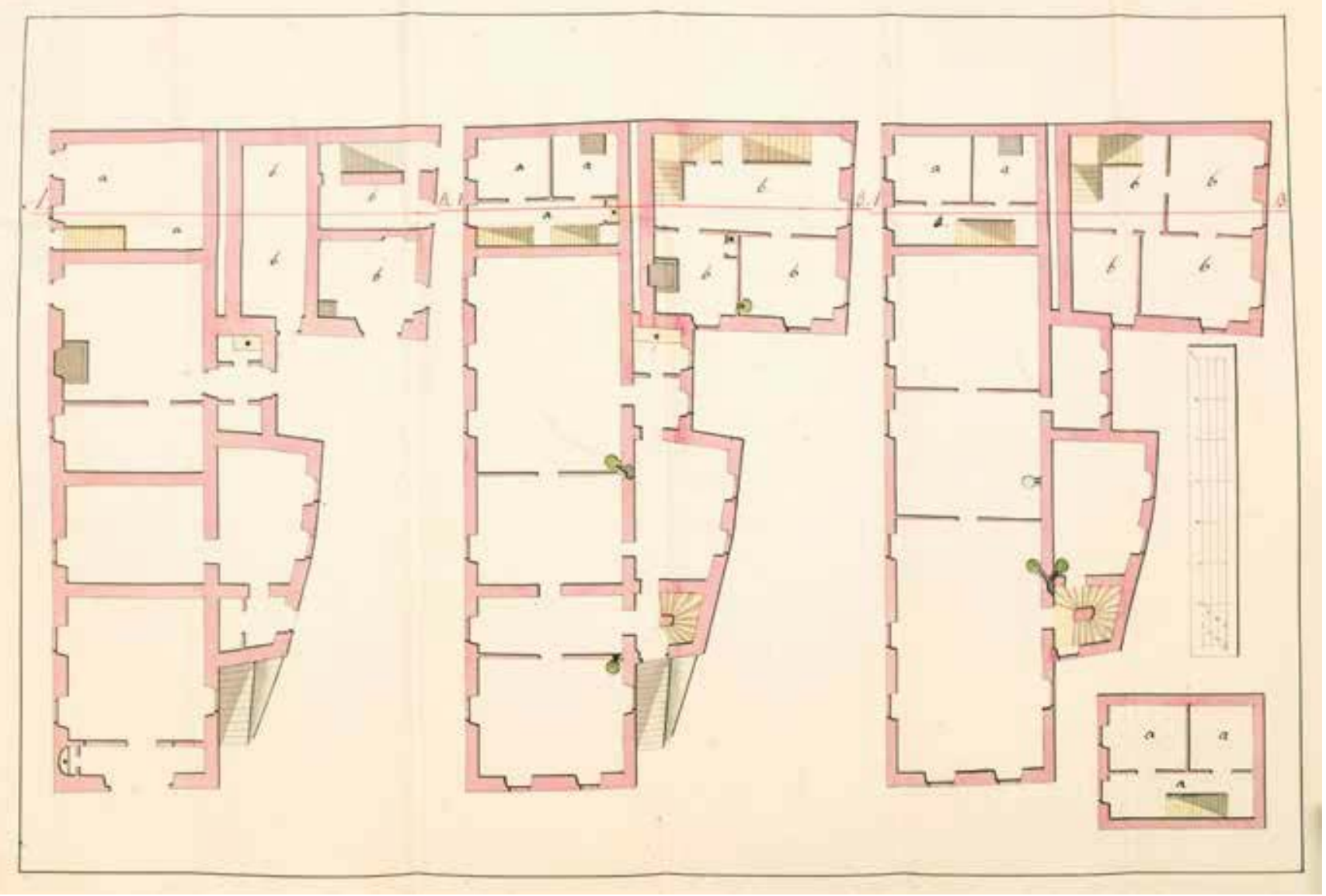




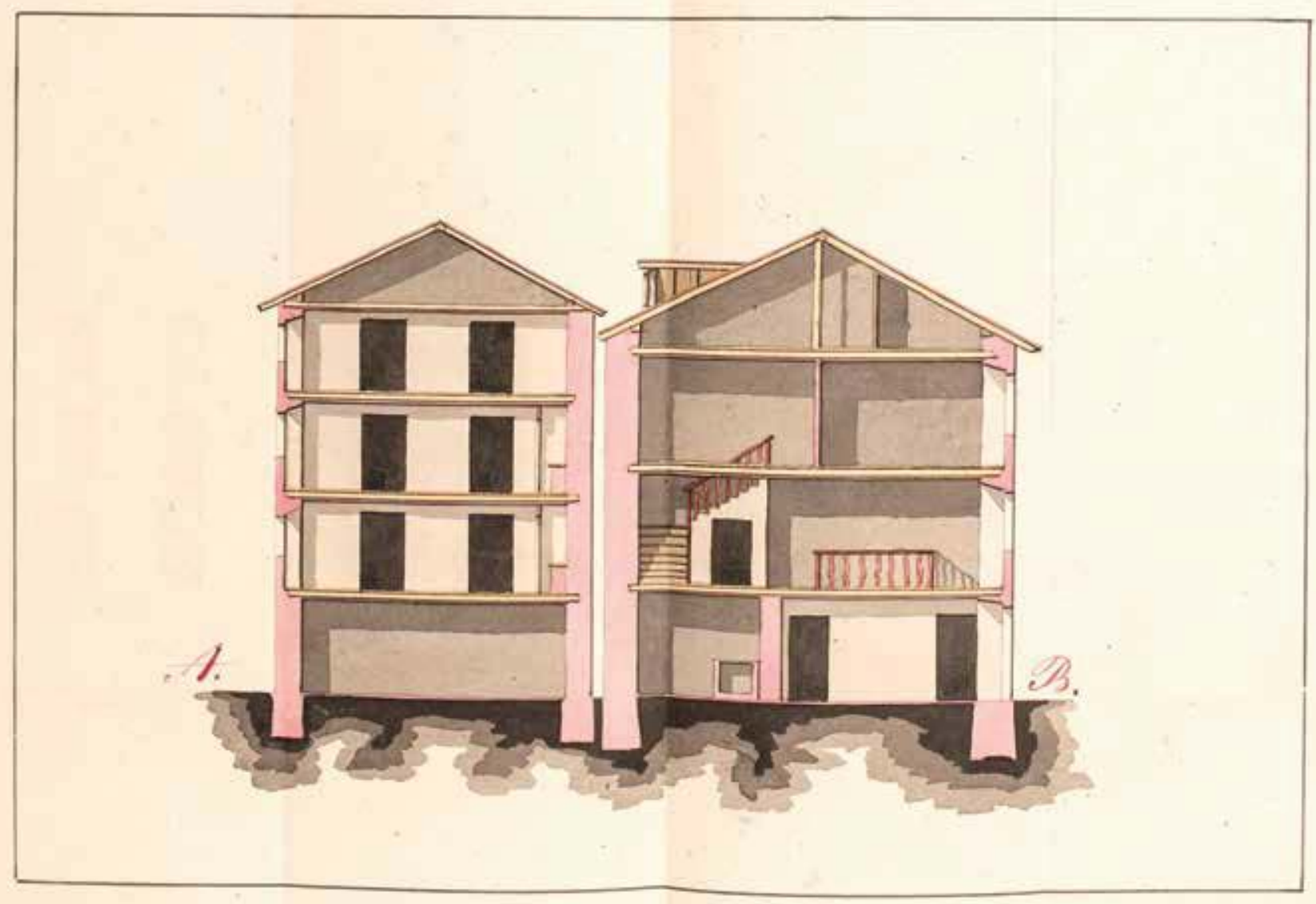

7b. Projekt za adaptaciju zgrade i pripojenje susjednih kuća, presjek, Adam Olf, 1832.

Plan for the renovation of the building and adjoining the neighbouring houses, cross-section, Adam Olf, 1832

va potrebnih radova. ${ }^{50}$ Ona je uključivala zidarske radove s probijanjem novih otvora, uklanjanje postojećih stuba, postavljanje novih vrata (ukupno 4), te popravci postojećih vrata i prozora. Ukupni je predviđeni iznos bio 240 forinti, što je svakako bio manji trošak od onoga predviđena za kupnju nove zgrade. U priloženim nacrtima, tlocrtima svih triju etaža te presjeku kroz kuće Fumulo i Fanello, doznaje se o tadašnjoj organizaciji unutrašnjeg prostora vijećnice. Jasno se vidi da je na svim etažama prostor podijeljen poprečnim zidovima na manje jedinice, a veća dvorana u dužini tri osi nalazi se tek na drugom katu. Također su vidljive i sve prigradnje uz istočno pročelje. Sjeverozapadna je susjedna kuća bila nešto viša i imala je i četvrtu etažu. Građevine nisu bile međusobno povezane, a velik broj zasebnih ulaza u pojedine prostorije odgovarao je potrebama funkcioniranja množine gradskih ureda (gradske uprave, policije, suda, arhiva, straže). Do realizacije projekta, međutim, nikad nije došlo jer su postojeće dvije kuće i danas odvojene. Konačno je 1833. ipak otkupljen prostor u augustinskom samostanu, a dvije godine poslije, 1835., onamo su preseljeni općinski uredi. ${ }^{51}$

Stara je pak vijećnica 1838. prodana trgovcu Francescu Battagliariniju ${ }^{52}$ te od tada do danas funkcionira kao stambenotrgovačka zgrada. Battagliarini je već i prije imao u najmu prizemni prostor i koristio ga kao dućan. ${ }^{53}$ Tridesetih je godina zgrada bila u lošem stanju, o čemu svjedoče opetovani zahtjevi za popravcima kao i uređenju unutrašnjosti te iznosima potrebnim za plaćanje zidara.$^{54} \mathrm{~S}$ obzirom na promjenu vlasnika, s pročelja zgrade bili su uklonjeni tragovi nekadašnje javne funkcije, a navodno je tek 1876. godine skinuta kamena ploča s natpisom i likom okrunjenoga kraljevskog orla, ${ }^{55}$ što se poklopilo s velikom obnovom bivšeg augustinskog samostana, u kojem je tada djelovala gradska uprava.

Na karti grada iz 1889. godine zgrada je označena kućnim brojem 1 na adresi Via San Vito (današnja Medulićeva), a u pripadnom popisu vlasnika navodi se Arturo Jellouscheg mlađi. ${ }^{56} \mathrm{~S}$ kraja 19. stoljeća potječe nekoliko starih fotografija Koblerova trga na kojima se nazire južno pročelje zgrade, kao i to da je veliki prostor prizemlja tada u najmu trgovca Anderlića. Godine 1912. vlasnik prizemlja Perini daje urediti taj prostor za Kino Abbazia (sl. 8). ${ }^{57}$ Pritom dolazi do rušenja tankih pregradnih zidova kod glavnog ulaza s južne strane te izgradnje pozornice s lučnim otvorom u sjevernom dijelu. U Drugom svjetskom ratu u bombardiranju Rijeke stradalo je više blokova unutar stare gradske jezgre, pa tako i onaj koji se nalazio jugozapadno od vijećnice. Rušenjem tog bloka bivša je vijećnica postala dominantna građevina na Koblerovu trgu (sl. 9), a takva će ostati sve do izgradnje nove zgrade na mjestu porušenoga bloka sedamdesetih godina 20. stoljeća. 


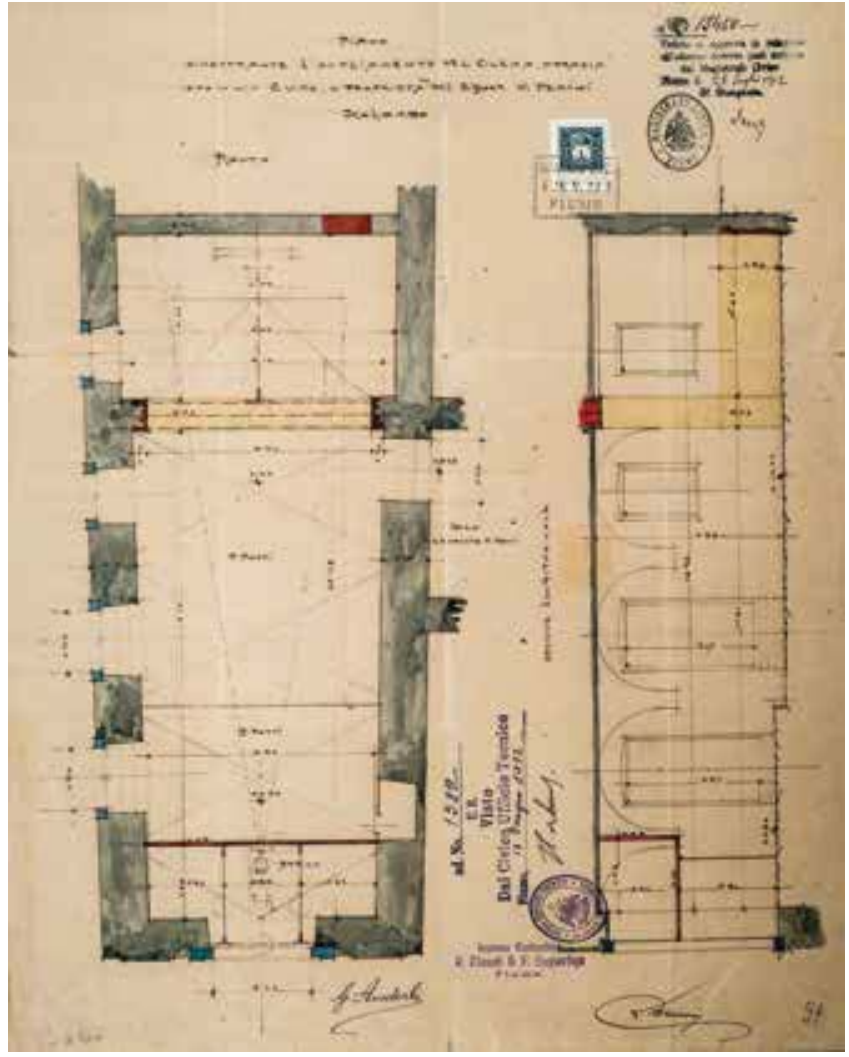

8. Projekt uređenja Kina Abbazia u vlasništvu V. Perinija, u prizemlju nekadašnje vijećnice, 1912.

Plan for repurposing the building to Abbazia Cinema owned by $V$. Perini, 1912

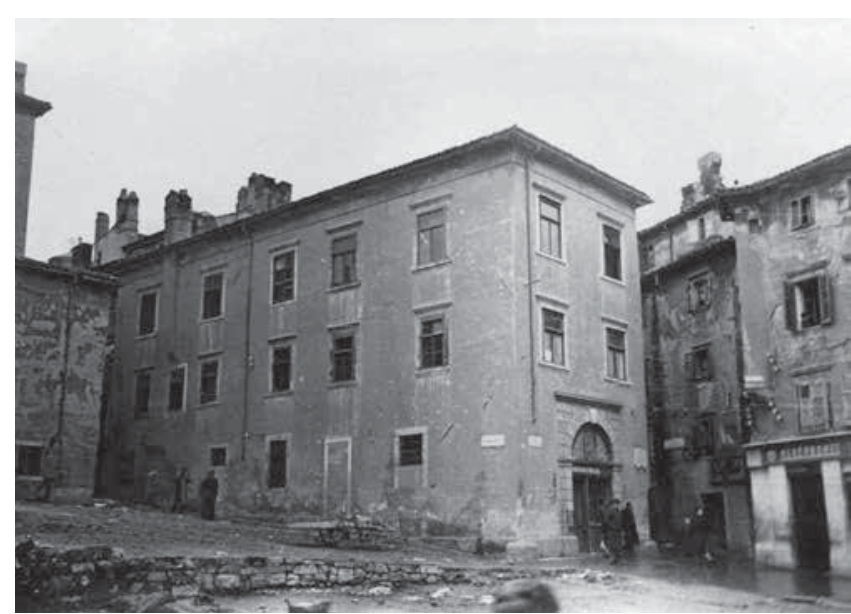

9. Bivša vijećnica nakon rušenja bloka kuća zapadno od nje, 1954. Former town hall after the demolition of the neighbouring houses to the west, 1954

\section{Konzervatorska istraživanja građevnih slojeva zgrade}

Provedenim sondažnim istraživanjima 2017. godine obuhvaćena su pročelja zgrade, a nakon toga je bila obijena sva žbuka s pročelja, pa su se dobro mogli vidjeti spojevi vanjskih zidova, a time i razlučiti građevni razvoj zgrade. Već je na prvi pogled, odnosno na pojavu rizalita, dilatacija te nejednake visine pojedinih dijelova, uočljivo da je zgrada građena $u$ nekoliko faza. Na prikazima koje ovdje donosimo (sl. 10), označena je datacija zidova te otvora, tj. prozora i vrata,
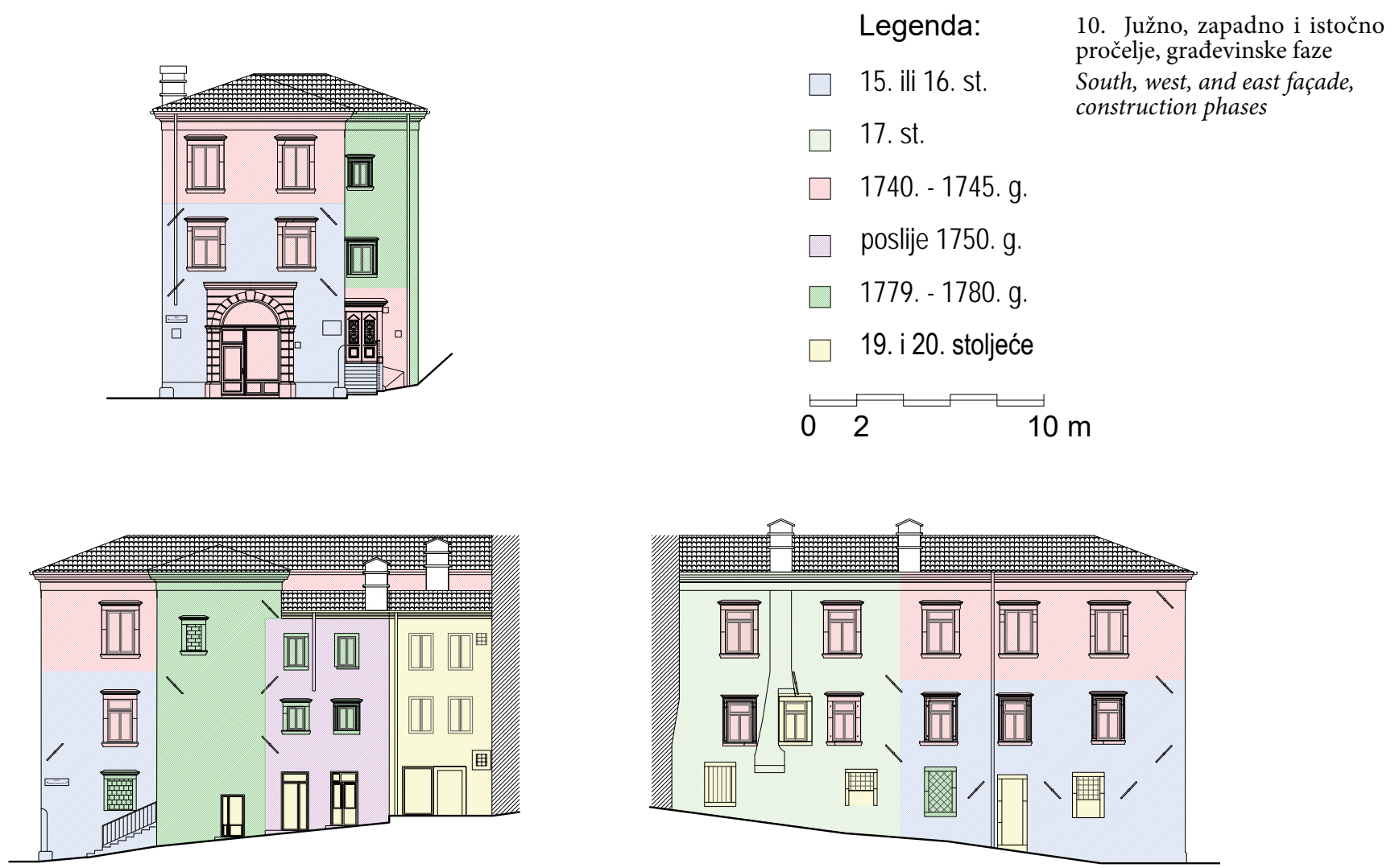
prema vremenu kada su uspostavljeni u današnjem formatu i obliku. S obzirom na slojevitost, ne treba zaboraviti da su se na njihovim mjestima mogli nalaziti raniji otvori, kao i to da su mnogi kameni elementi sekundarno upotrijebljeni.

Može se pretpostaviti da je najstariji dio kuće onaj južni, s obzirom da je zgrada na tom mjestu, okrenuta prema Koblerovu trgu i položena u regulacijskoj liniji Užarske ulice, već vidljiva na planovima grada iz 16 . stoljeća, od kada se spominju i najraniji zapisi o postojanju vijećnice. Ne treba dakako isključiti ni mogućnost da te najranije strukture potječu iz 15. stoljeća jer je kuća kapetana De Durra, poslije prenamijenjena za vijećnicu, već postojala 1484. godine. Dokumenti iz 18. stoljeća opisuju dogradnju drugoga kata, što znači da je zgrada koja se dotad ovdje nalazila bila jednokatna. Je li imala kakav luk ili arkade na pročelju, zasad ne možemo znati. ${ }^{58}$

Na prvobitnu manju kuću okrenutu prema Koblerovu trgu, bila je u nekom vremenu nadozidana susjedna, sjeverno smještena kuća, koja je sezala do razine drugog kata. Naime, na zapadnom je pročelju između druge i treće osi sa sjevera utvrđena okomita reška koja se pruža cijelom visinom pročelja, a koja ukazuje na spajanje kamene građe dviju različitih građevina. Ona je osobito vidljiva u zoni drugoga kata, što znači da je susjedna kuća već bila dvokatna u vrijeme njezina spajanja s vijećnicom. Dvije su kuće spojene upravo prilikom nadogradnje drugoga kata vijećnice u 18. stoljeću, s obzirom da su u obje ugrađeni istovjetni kameni prozori, kako u prvom, tako i u drugom katu.

Arhivski zapisi, naime, jasno opisuju nadogradnju drugog kata 1740.-1745. prema projektu Antonija de Vernede. Sondiranje je pokazalo promjenu u kontinuitetu građe između prvog i drugog kata, s ubacivanjem horizontalnih redova opeke u pretežno kamenoj građi zida, pa se može potvrditi da je doista naknadno izvedeno povišenje starog dijela vijećnice za još jedan kat.

Nadogradnjom drugoga kata ugrađena je većina današnjih velikih prozora koje karakteriziraju dekorativne profilirane klupčice, nadstrešnice, a mjestimično i doprozornici. Neki prozori s nizovima zubaca ispod nadstrešnice ili profilacijom doprozornika upućuju na nastanak u 16. stoljeću, a u cijelosti podsjećaju na prozore i portal kuće Gašpara Knežića iz 1588. u Šporerovoj 4, što je već zapazila i Radmila Matejčić. ${ }^{59}$ No na vijećnici su ti prozori sekundarno ugrađeni na ta mjesta. Naime, iznad prozora prvog kata u zidu su znatno kraći opečni nadvoji namijenjeni užim prozorima, dok su na drugom katu nadvoji iste širine. To znači da u prvom katu kameni okviri nisu bili prvotno namijenjeni za te otvore. Iako njihovo oblikovanje ukazuje da potječu iz 16. stoljeća, ne možemo znati jesu li izvorno stajali na vijećnici ili nekoj drugoj zgradi.

Nadalje, svi kameni prozori ne samo da su prošireni nego su i povišeni, s ubacivanjem kraćih kamenih greda kao nadopuna doprozornika, slične profilacije, ali nešto drukčije klesarske obrade (sl. 11). Budući da se isto javlja i na prozorima drugoga kata iz vremena Vernedine obnove, zasigurno je i ondje dijelom iskorišten raniji materijal. ${ }^{60}$ Vernedina obnova

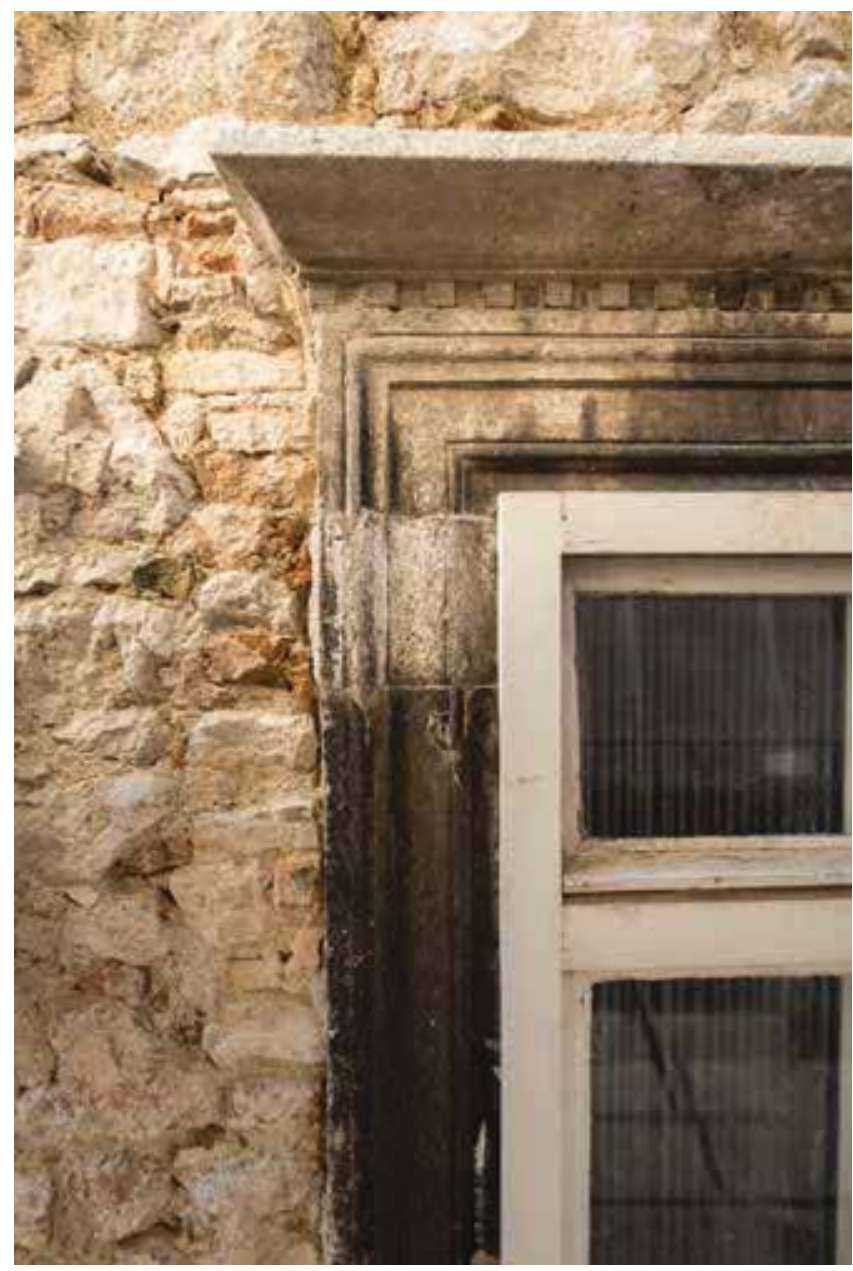

11. Detalj prozora prvog kata s vidljivom opečnom građom uz kameni okvir koja sugerira naknadnu ugradnju, kao i naknadno ubačeni fragment doprozornika drukčije obrade površine

Detail of the first-floor window, with bricks around the stone frame suggesting a later insertion and a subsequently inserted fragment

značila je i izgradnju današnjega velikog, lučno zaključena portala (sl. 12) ${ }^{61}$ te ugradnju spomenutih ploča s natpisima, čija su izvorna mjesta pronađena sondiranjem. ${ }^{62}$

Nadogradnja drugog kata podrazumijevala je, dakako, i rješavanje pitanja stubišne komunikacije između etaža, ali čini se da su od nje danas ostali samo tragovi. Sondiranje je pokazalo da je današnji stubišni rizalit nastao u nekoliko faza. Čini se da je prije Vernede postojalo vanjsko otvoreno stubište na koje upućuju i povijesni zapisi te da ga je Verneda zadržao, barem njegov donji dio, pa na mjestu uspona za gornje katove izveo novo stubište u rizalitnom bloku. Zadržavanje starijega donjeg dijela vanjskog stubišta odražava i činjenica da je portal ulaza u rizalit smješten uza sam rub istočnoga perimetralnog zida zgrade, na način da mu taj zid zaklanja lijevi dovratnik, pa je portal morao biti naknadno ugrađen na to mjesto prilagođavajući se već prije određenu položaju vanjskih stuba.

No, prije dogradnje rizalita u današnjoj visini, dogodila se izgradnja još jednog nižeg, tzv. sjevernog rizalita, s kojim je 

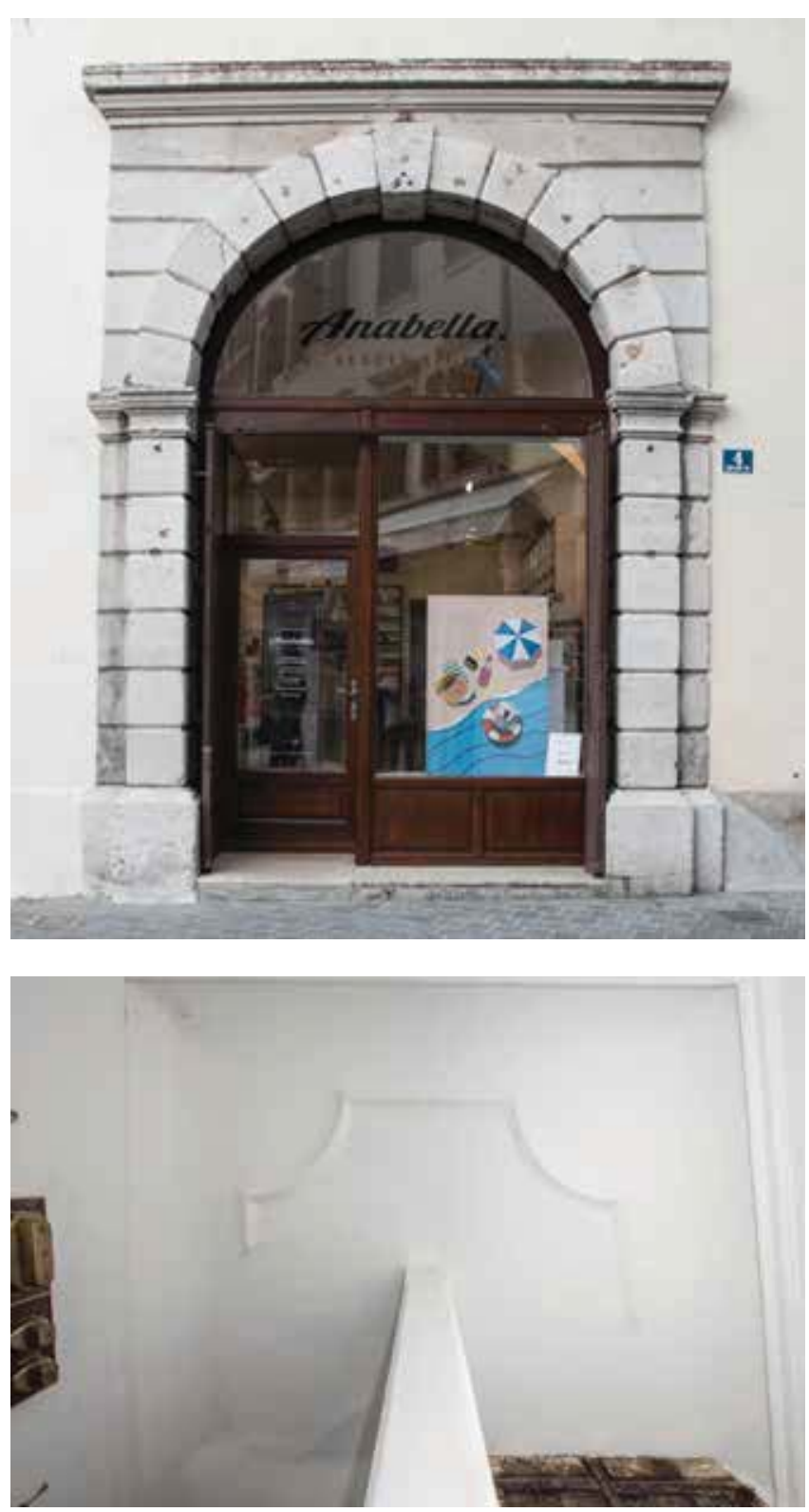

12. Glavni portal na južnom pročelju Main portal in the south façade

13. Štuko medaljon na svodu stubišta Stucco medallion in the staircase vault

on danas spojen u istoj regulacijkkoj liniji, premda nisu iste visine. Taj je sjeverni rizalit stariji jer je na njihovu spoju pronađena izdužena okomita reška i žbuka koja se nekad nalazila na njegovu sjevernom pročelju. ${ }^{63}$ Budući da se sjeverni rizalit prislanja uz glavni korpus zgrade sve do razine drugoga kata, doduše, ne i do sama vijenca, on nastaje naknadno u odnosu na Vernedinu dogradnju drugoga kata. Iz toga posredno zaključujemo da glavni stubišni rizalit koji je započeo Verneda nastaje u svojoj današnjoj visini tek nakon izgradnje sjevernog rizalita. Veliki potres koji je pogodio Rijeku 1750. i u kojem je vijećnica bila oštećena do te mjere da je morala biti iseljena, mogao je biti uzrok rušenja prvotne Vernedine stubišne komunikacije te povod za manju adaptaciju zgrade
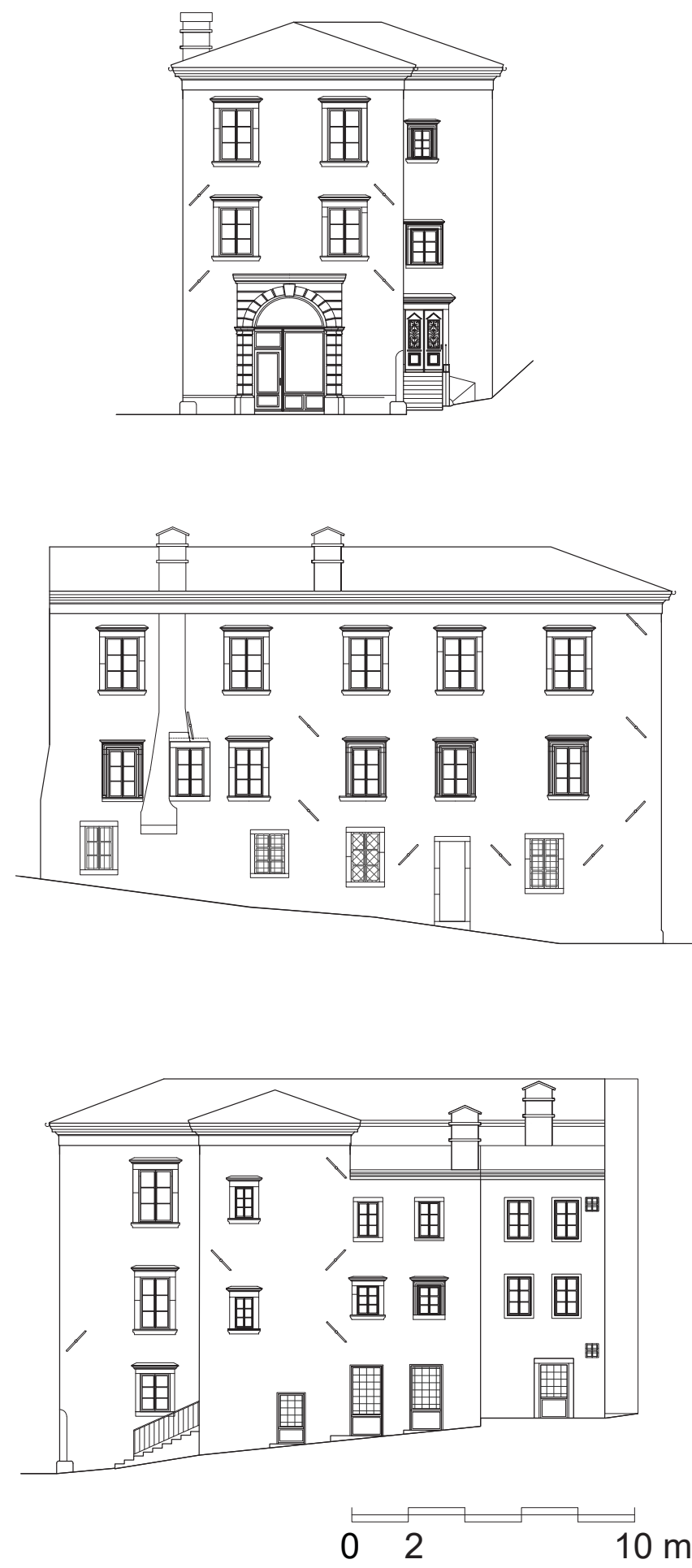

14. Južno, zapadno i istočno pročelje, prijedlog prezentacije South, west and east façade, presentation proposal

tijekom koje je izveden sjeverni rizalit. On je izuzetno loše, miješane građe od kamena i opeke, a svi prozorski okviri prozora sekundarno su ugrađeni. Kada se sve uzme u obzir, sjeverni je rizalit bio tek provizorna adaptacija kojom se zgrada nakon potresa što prije htjela ponovo staviti u funkciju.

Velika obnova koja je uslijedila 1779.-1780., a tijekom koje se slikovito, i vjerojatno neistinito, navodi da je zgrada obnov- 
ljena »kao u vrijeme prvotne izgradnje kapetana De Dura«, mogla je biti vrijeme dogradnje glavnoga stubišnog rizalita $\mathrm{u}$ današnjoj visini, ${ }^{64}$ pri čemu su onda iskorištene Vernedine strukture te je izveden spoj na niži sjeverni rizalit u istoj regulacijskoj liniji. Izravnanje regulacijske linije potvrđuje i nalaz na južnom pročelju stubišnog rizalita, odnosno naknadna izvedba zadebljanja na već pravilno formiran jugoistočni ugao, a koji se potom u punoj ravnini i kontinuiranoj građi nastavlja u prvom i drugom katu. Isti nalaz, odnosno reška, pokazuje da je južni zid rizalita u zoni prizemlja starija struktura, a to bi, sukladno gore opisanu, mogli biti ostaci prvotnoga Vernedina rizalita s portalom ulaza na stubište.

Čak i bez detaljna ulaženja u analizu unutrašnjeg prostora, možemo reći da je višekratna adaptacija stubišta dovela ne samo do pomicanja vanjskih otvora nego i odmorišta s kojih se prema susjednim prostorijama pristupa stubama, a također je u nekom trenutku barokni štuko medaljon (sl. 13) na svodu stubišta napola presječen zidom koji nosi stubišnu konstrukciju.

Osim dva spojena rizalita, došlo je poslije i do treće prigradnje uz istočno pročelje vijećnice, točnije uz njegov krajnji desni, odnosno sjeverni dio, na spoju sa susjednom kućom. Ta je prigradnja znatno uvučena u odnosu na regulacijsku liniju obaju rizalita, ali je iste visine kao sjeverni rizalit. Na pročelju te prigradnje prozori su nepravilno klesanih i nedorađenih kamenih okvira koji nisu bili vidljivi nego prežbukani.

Na temelju konzervatorskih istraživanja, faze razvoja zgrade mogle su se tek načelno razlučiti jer je pri svakoj obnovi došlo do sekundarna korištenja postojećeg materijala, od-

\section{Bilješke}

1

Ovaj je rad sufinancirala Hrvatska zaklada za znanost projektom IP-2016-06-1265 ET TIBI DABO: naručitelji i donatori umjetnina u Istri, Hrvatskom primorju i sjevernoj Dalmaciji od 1300. do 1800. godine.

2

Istraživanja su opisana u elaboratu: PETAR PUHMAJER KRASANKA MAJER JURIŠIĆ - IVAN BRAUT, Rijeka. Zgrada u Ul. Andrije Medulića 1 (Stara gradska vijećnica). Elaborat konzervatorsko-restauratorskih istraživanja pročelja, Hrvatski restauratorski zavod, Zagreb, 2017.

3

O funkciji vijećnice i lože u Hrvatskom primorju i Dalmaciji više u: KRASANKA MAJER JURIŠIĆ, Arhitektura vlasti i suda, Zagreb, 2017.

4

GIOVANNI KOBLER, Memorie per la storia della liburnica città di Fiume, sv. 2, Fiume, 1896., 45; SILVINO GIGANTE, Fiume nel Quattrocento, Fiume, 1913., 41, 60-61; SILVINO GIGANTE, Fiume nel secolo XVI, u: Bulettino per la storia patria, (Fiume, 1918.), 96. nosno stariji su kameni okviri često ponovo ugrađeni na druga mjesta, što je znatno otežalo točno utvrđivanje faza. Prijedlogom prezentacije bilo je predviđeno zadržavanje svih utvrđenih faza te manje korekcije otvora i pojedinih detalja prema nalazima (sl. 14).

\section{Zaključak}

Stara gradska vijećnica u Rijeci građevinski je slojevito zdanje u kojemu se nalaze materijalni tragovi od 15. ili 16. pa sve do 20. stoljeća. Istraživanje arhivskih izvora u velikoj je mjeri potvrdilo promjene na zgradi te pojasnilo neke dosad nepoznate okolnosti funkcioniranja gradske vlasti i procesa obnove javne zgrade u novom vijeku. Ti se procesi nisu uvijek odvijali planirano ni s nekom vizijom, nego su bili odraz potreba i mogućnosti vremena pa često nisu rezultirali velikim djelima arhitekture i dizajna. Javna je zgrada zadovoljavala svoju elementarnu funkciju u vrijeme kada je Rijeka imala svega nekoliko tisuća stanovnika pa se mogu razumjeti htijenja i potrebe gradske vlasti, koja su rezultirala čestim adaptacijama i dograđivanjima. Zanimljivo je da se u razdoblju procvata Rijeke u kasnom 18. stoljeću njezini prostori koriste za razna društvena i poslovna događanja te javne sadržaje, a tomu je pogodovala i činjenica da se ona nalazi u samu gradskom središtu. Organički razvoj od prvotne građanske kuće do malene barokne palače, stiješnjene na glavnom križištu ulica sa središnjim trgom, pokazuju koliko je njezina arhitektura srasla sa skromnim urbanističkim mjerilom novovjekovnoga grada.

5

ALFREDO FEST, Fiume nel secolo XV, u: Bullettino della deputazione fiumana di storia patria, 3 (1912.), 31, 53.

6

GIOVANNI KOBLER (bilj. 4), 41. Loža je 1484. bila na gradskom trgu, što se zaključuje prema donaciji gradskog kapetana De Durra jednoj kući uz ložu. Vidi: ALFREDO FEST (bilj. 5), 53. Arheološka istraživanja rađena su na sjeverozapadnoj strani Koblerova trga te su utvrđene, osim antičkih, i izvjesne novovjekovne strukture, točnije sa sjeverozapadne i južne strane današnje fontane, ali zasad nijedna nije povezana s mogućim smještajem lože ili vijećnice. Vidi: JOSIP VIŠNJIĆ - SINIŠA PAMIĆ, Stručno izvješće o arheološkom istraživanju Trga Ivana Koblera u riječkom Starom gradu tijekom 2014. godine, Hrvatski restauratorski zavod, Juršići, 2014.

7 GIUSEPPE VIEZZOLI, Contributi alla Storia di Fiume nel Settecento, u: Fiume rivista semestrale, 11-12 (1936.), 166.

8

Prikaz gradske lože i vijećnice nacrtao je Riccardo Gigante, a objavljen je u: SILVINO GIGANTE (bilj. 4, 1913.). 
9

GIOVANNI KOBLER (bilj. 4), 45.

10

Napisao ga je Goffredo Confalonieri, pravni stručnjak podrijetlom iz Ferrare, i to u četiri knjige. U prvoj knjizi statuta određen je način izbora članova Malog i Velikog vijeća, sudaca, kapetana, vikara, sindaka i drugih gradskih dužnosnika, opisan je rad gradskih struktura i ureda i njihova prava i obaveze, u drugoj su knjizi definirani javni poslovi, u trećoj kriminalne radnje, a u četvrtoj »izvanredni « poslovi. SILVINO GIGANTE, Storia del comune di Fiume, Fiume, 1928., 56.

11

SILVINO GIGANTE (bilj. 10), 58.

12

GIAN MARIA TORCOLETTI, La chiesa e il convento degli agostiniani di Fiume, Fiume, 1944., 64.

13

Državni arhiv u Rijeci (dalje: HR-DARI-250), Samostan reda pustinjaka sv. Augustina u Rijeci 1418.-1788., kutija 2, Pergamena 19. Isprava ovjerena od bilježnika Dominika Ravizze od 6. travnja 1532. kojom samostan augustinaca prodaje riječkoj općini kuću kraj lože, uz uvjet da ga općina trajno oslobodi trošarine na stoku.

14

HR-DARI-250, Samostan reda pustinjaka sv. Augustina u Rijeci 1418.-1788., kutija 6. Prijepis ugovora od 13. lipnja 1484. između Baldassarea de Durra i priora augustinskog samostana Gašpara, kojim De Durr daje samostanu kuću u Rijeci za jednu misu svakog petka u kapeli Presvetog Trojstva, gdje je pokopana njegova supruga Katarina. Kamena ploča s izvornim natpisom nalazi se $u$ augustinskom samostanu, a njezin prijepis i prijevod vidi u: IVA JAZBEC TOMAIĆ - ŽELJKO BISTROVIĆ - MATEJA JERMAN - IVAN BRAUT, Sedam stoljeća augustinskog samostana u Rijeci, elaborat I, Katedra za umjetnost ranog novog vijeka, Odsjek za povijest umjetnosti, Filozofski fakultet u Rijeci, Rijeka, 2014., 48-51.

15

GIOVANNI KOBLER (bilj. 4), 45. Podatak se navodi u više izvora, čak i u 18. stoljeću kada gradski zapisnici bilježe da je Baldassar de Durr, tadašnji namjesnik u Rijeci, 1484. godine svoju kuću prepustio samostanu, te da je ona od 1532. godine bila gradska palača. Budući da je kuća prepuštena općini, samostan je trajno oslobođen poreza na vino s vlastitih posjeda. - HR-DARI-32, Zapisnici sjednica gradskog magistrata za godine 1779. i 1780. Kuća se u 15. stoljeću spominje i kao kuća Gresani, a kapetan De Durr uredio je za potrebe svojeg stanovanja u vrijeme boravka u Rijeci. Po završetku službe ostavio ju je augustinskom samostanu. Vidi: NANA PALINIĆ - IVAN KUSTIĆ, Povijesni razvitak Koblerova trga u Rijeci - temelj za revitalizaciju, u: Zbornik radova Građevinskog fakulteta Sveučilišta u Rijeci, 16 (2013.), 132.

16

RICCARDO GIGANTE, Il terremoto nel 1750, u: La vedetta d'Italia, 11. 1. 1945.

17

RADMILA MATEJČIĆ, Kako čitati grad. Rijeka jučer i danas, Rijeka, 2007., 79.

18

GIOVANNI KOBLER (bilj. 4), 45. Prema nekim podacima ploča je postavljena 1767. godine. Vidi: GIAN MARIA TORCOLETTI (bilj. 12), 64; Radmila Matejčić pak smatra da je ploču, izvorno iz vremena prvog uređenja zgrade, odnosno iz 1560. godine,
Verneda zadržao i postavio nakon dogradnje drugog kata na novu poziciju. Vidi: RADMILA MATEJČIĆ (bilj. 17), 81.

19

Österreichische Nationalbibliothek, Cod. 8607, fol. 3r, Fiume - Ichnographiae quadraginta et delineationes propugnaculorum Graecii, Labaci et illorum in Hungaria, Croatia et Dalmatia contra Turcas (Inventarnummer E 31200C).

20

Österreichisches Staatsarchiv, Kriegsarchiv (dalje: OSTA-KA), Kartensammlung, sign. GIh 171.

21

MATTHÄUS MERIAN, Topographia Provinciarum Austriacarū, Austriae, Styriae, Carinthiae, Carniolae, Tyrolis etc., Das ist Beschreibung Vnd Abbildung der fürnembsten Stätt Vnd Plätz in den Osterreichischen Landen Vnder vnd OberOsterreich, Steyer, Kärndten, Crain Vnd Tyrol, Frankfurt, 1679., 3. izdanje.

22

RADMILA MATEJČIĆ (bilj. 17), 81.

23

O funkcioniranju gradske uprave i sudstva u 18. stoljeću vidi: GIUSEPPE VIEZZOLI, Contributi alla Storia di Fiume nel Settecento, u: Fiume rivista semestrale, 10 (1933.), 135-178.

24

GIUSEPPE VIEZZOLI (bilj. 7), 171.

25

Verneda je projektirao i izveo palaču biskupa Benzonija u drugoj četvrtini 18. stoljeća, kao i vlastitu kuću na Rovu. Obnovio je benediktinsku crkvu sv. Roka nakon potresa 1750., kojoj je sagradio zvonik. U Rijeci je radio brojne urbanističke regulacije, a spominje se i kod gradnje brodogradilišta u Kraljevici te obnove ruševnog Starog grada u Ozlju (1743.-1753.). Vidi: RADMILA MATEJČIĆ, Barok u Istri i Hrvatskom primorju, u: Barok u Hrvatskoj, Zagreb, 1982., 420-422; RASTKO SCHWALBA, Barokizacija Rijeke i udio inženjera A. Vernede u njenoj urbanizaciji, u: Novi Kamov, 4 (2004.), 100-109; PETAR PUHMAJER - KRASANKA MAJER JURIŠIĆ, Palača Benzoni - primjer stambene arhitekture 18. stoljeća u riječkom Starom gradu, u: Ars Adriatica, 6 (2016.), 186-188.

26

GIAN MARIA TORCOLETTI (bilj. 12), 64.

27

„Fù proposto che avendo riconosciuto li Spettabili Signori Giudici in occasione che nel principio dell'Inverno ha dovuto sortir dal quartiere Pubblico il moderno Cesareo Canceliere qualmt.e la casa assegnata per sua abitazione e specialmente il tetto a causa dell'antichità minazia evidente ruina e sia necessaria un Soda riparazione e dimandano il Pubblico assenso per intrapender la medema. Fù risolto che dovendosi per il premesso effetto atterare e nuovamente rimettere il tetto nella Casa della Cancelleria si debba nello stesso tempo alzare un altro piano sopra lattuale Sala Pubblicha di maniera che questa in avvenire debba servire unicamente per tribunale Vicariale e la Segretaria per Archivio Cesareo e di spora si faccia il comodo per tenere il Consiglio e quello della Segretaria, dovendo però li Signori Giudici riguardo alla Spesa passare di concerto con li Signori Antonio Spingaroli e Teodoro Bono che in qualità d'Ecconomi vengono a loro aggiunti, e intanto al Cesareo Cancelliere viene placidato un congruo affitto, sinocche il suo quartiere si renderà abitabile." - HR-DARI-32, Zapisnici sjednica gradskog magistrata, 12. 3. 1740., 549. 
28

"...circa la fabbricha del Pubblico Palazzo... secondo il presente progetto del medesimo, circa l'alzamento del secondo piano, si debba preventivamente communicato ll Signore Capitanio de Verneda, e si in traprenda a misura della di lui oppinione ed approvazione, e non venendo approvato, venghi proposto in Consiglio: intanto circa la Spesa doveranno essere firmate tutte le polize dalli tre Signori Aggiunti Deputati (op. a. Teodoro Bono, Pietro Tremanini e conte de Staremberg) « - HR-DARI-32, Zapisnici sjednica gradskog magistrata, 14. 7. 1740., 552.

\section{9}

HR-DARI-32, Zapisnici sjednica gradskog magistrata, 28. 7. 1740., 554.

30

»Propose il Spetabile Signor Giudice della Magnifica Communità essersi radunato l'odierno Consiglio per trattare circa la fabbrica del Pubblico Pallazzo, che già da qualche tempo stà scuoperto: onde addimanda d'esser istrutto se l'abbia da alzare un altro appartamento, secondo la precedente determinazione, oppure attesa l'attuale pubblica impotenza di fare gran spesa con un semplice abbelimento di stucho cuoprirlo nella maniera come fù prima. Fù risolto che dalli Spetabili Signori Giudici e Deputati per via di gente perita si facia esaminare la situazione del pubblico Palazzo, e di ogni caso si potesse migliorare e ridure la sala del Consiglio, regollare compredendo nella sua larghezza il Spazio delle Scale, per dargli l'ingresso per quelle della Casa della Cesarea Cancelleria debba ciò farsi, purchè la spesa non ecceda oltre li ?675 d altri ?150. Senza pregiudizio della Cancelleria, altrimenti si debba riparare sul piede anticho." - HR-DARI-32, Zapisnici sjednica gradskog magistrata, 3. 8. 1740., 553.

31

GIUSEPPE VIEZZOLI (bilj. 7), 171. Primjerice, sudski je vikar neko vrijeme koristio kuću nasljednika Francesca Stemberga, a potom poželio unajmiti kuću Zanchi što bi javnu blagajnu dodatno opteretilo jer je najam bio skuplji pa je vikaru naloženo da se strpi dok radovi ne budu završeni. - HR-DARI-32, Zapisnici sjednica gradskog magistrata (godine 1682.-1762.), 18. 8. 1744., 8 .

\section{2}

"In oltre furono incaricati li spettabili signori giudici alla scadenza delli secondi quartali continuare la fabbricha del Palazzo Pubblico e primieramente dar principio alla Cancelleria ed archivio per esimersi dall'affitto e successivamente provedere li materiali per il palazzo accio farsi possa col legname stagionato. - HR-DARI-32, Zapisnici sjednica gradskog magistrata, 29. 4. 1741., 567.

33

HR-DARI-32, Zapisnici sjednica gradskog magistrata (za god. 1682.-1762.), 14. 9. 1742., 574.

34

HR-DARI-32, Zapisnici sjednica gradskog magistrata (za god. 1682.-1762.), 30. 3. 1743., 576.

35

„Fu risolto che per parte di questo Magistrato Pubblico debba esser addobata e froanata con iscrizioni allusive la facciata del suo Palazzo e illuminate le finestre con due torcie per ciascheduna...«. - HR-DARI-32, Zapisnici sjednica gradskog magistrata, 14. 3. 1741., 560 .

36

GIOVANNI KOBLER (bilj. 4), 45-46.

37

HR-DARI-32, Zapisnici sjednica gradskog magistrata (za god. 1682.-1762.), 11. 11. 1745., 589. i dalje. Još u ljeto prethodne godine sjednice su održavane u kaštelu. - HR-DARI-32, Zapisnici sjednica gradskog magistrata (za god. 1682.-1762.), 27. 6. 1744., 8.

38

RICCARDO GIGANTE (bilj. 16).

39

HR-DARI-32, Zapisnici sjednica gradskog magistrata, 22. 5. 1751., 618.

40

GIUSEPPE VIEZZOLI (bilj. 7), 172.

41

Tako je, primjerice, 1764. godine, u vrijeme karnevala, općina sklopila ugovor s Giulijem Morettijem koji je ondje organizirao plesove dvaput tjedno. Vidi: GIUSEPPE VIEZZOLI (bilj. 7), 150.

42

GIOVANNI KOBLER (bilj. 4), 45-46.

43

GIUSEPPE VIEZZOLI (bilj. 7), 172. Prije kasina u prizemlju je neko vrijeme bila trgovina mesnih prerađevina Masè. Vidi također: RICCARDO GIGANTE (bilj. 16).

44

HR-DARI-32, Zapisnici sjednica gradskog magistrata za godine 1779. i 1780., 16. 11. 1779., 455-456. (Prijevod s latinskog: dr. sc. Šime Demo).

45

HR-DARI-32, ibid.

46

Iz obližnje kavane Grigioni posluživali su napitke i sladoled. Vidi: GIOVANNI KOBLER (bilj. 4), 46.

47

„Na sredi je krasna, u moje vreme ponovna i narešna vjećenica (domus praetoria), italijanski palazzo, na dva sloga; ali kvar da nejma krasnju ulazu (introitum, uhodje) i prostranja stupališća (scalae, gradus), koja su tijesno na puž uzgrađena. Od zada bi u moje pameće (mea memoria) kavanica u koju vlastelini i većeslastni gradanici (cives maiori inter ceteros pollentes austoritate) po poludnje dohađahu na razgovor i kavu piti, i igrati na biljar ili boćenar oli izbojak (trudes), ili na igraćenice (alea)...«. Vidi: NANA PALINIĆ - IVAN KUSTIĆ (bilj. 15), s pozivom na WACŁAW TWARDZIK, Opis Rijeke s početka 19. stoljeća iz pera Josipa Završnika, u: Dometi, 4 (1987.), 265-278.

48

OSTA-KA, Kartensammlung, sign. GIh 175.

49

PETAR PUHMAJER - KRASANKA MAJER JURIŠIĆ - IVAN BRAUT (bilj. 2), 26

50

HR-DARI-32, Izdvojeni nacrti, kut. 284. spisi br. 82 i 1207.

51

GIOVANNI KOBLER (bilj. 4), 46.

52

GIOVANNI KOBLER (bilj. 4), 46.

53

HR-DARI-32, Spisi gradskog magistrata za godine 1833.-1835., prema: Registro magistratura dall' anno 1833 sino tutto l'anno 1835. Spisi 2341 od 25. 9. 1833. i 2631 od 23. 10. 1833. 
54

HR-DARI-32, Spisi gradskog magistrata za godine 1833.-1835., prema: Registro magistratura dallanno 1833 sino tutto l'anno 1835. Spisi 2727 od 16. 11. 1833., 2986 od 12. 12. 1833.

55

GIOVANNI KOBLER (bilj. 4), 45. Navodno je ploča postavljena 1767. godine. Vidi također: GIAN MARIA TORCOLETTI (bilj. 12), 64 .

56

HR-DARI-341, Zemljišno-knjižni ured grada Rijeke, Fiume Város. Hàzszàm Jegyzèk / Fiume Città. Elenco dei numeri di casa 1889. Compilato da Edoardo Suara geometra, 63.

57

HR-DARI, Tehnički ured grada Rijeke, kut. 161, 86/1912, A. Medulića 1, 162/1.

58

Sondiranjem oko portala pokušalo se utvrditi postojanje većeg zazidanog lučnog otvora u prizemlju, na koji ukazuju neki povijesni prikazi vijećnice, ali on nije utvrđen, čak ni nakon obijanja cjelokupne žbuke. Vidljiva je građa zida od lomljenog kamena bez tragova ranijih otvora. Vidi: PETAR PUHMAJER - KRASANKA MAJER JURIŠIĆ - IVAN BRAUT (bilj. 2), 125. Ako je raniji lučni otvor postojao, on se morao nalaziti upravo na mjestu današnjeg Vernedinog portala, čije su dimenzije pozamašne.

59

RADMILA MATEJČIĆ (bilj. 17), 81. Riječ je o tipičnom prozoru alla romana, kakav se javlja od druge polovice 15 . stoljeća diljem jadranske obale, primjerice, u Dubrovniku. Vidi: NADA GRUJIĆ, Kuća u Gradu. Studije o dubrovačkoj stambenoj arhitekturi 15. i 16. stoljeća, Dubrovnik, 2013., 48-49.
60

Na nekoliko mjesta su u ziđu utvrđene spolije. Najzanimljivija je ona koja čini ugaoni klesanac jugoistočnog ugla stubišnog rizalita u zoni između prvog i drugog kata, a riječ je o ulomku volute (podsjeća na jonske volute kapitela stupova u dvorcu Nova Kraljevica), ili jedna kamena greda sa štapnom profilacijom u jugozapadnom uglu drugog kata zgrade. Vidi: PETAR PUHMAJER - KRASANKA MAJER JURIŠIĆ - IVAN BRAUT (bilj. 2), 126.

61

Vernedinu portalu, inače, izuzetno sliči onaj na gradskim vratima u Kastvu, koji je na zaglavnom kamenu datiran u 1769. godinu, što govori o mogućim utjecajima riječke vijećnice na arhitekturu u okolici.

62

Sondiranje je pokazalo da se između prozora prvog i drugog kata nalaze velika pravokutna uleknuća u zidu i željezni klinovi za učvršćenje dviju ploča. Nakon obijanja žbuke uleknuća su se pokazala u punom formatu. Ispod postojećih uleknuća za dvije ploče, u zoni prvog kata, utvrđen je zazid, ali se zasad ne može reći je li i on služio za smještaj još neke ploče ili je možda riječ o ranijem zazidanom prozorskom otvoru.

63

Naime, u reški su utvrđeni klesanci koji su nekad rubili jugoistočni ugao tog rizalita te vanjska južna ploha koja je bila ožbukana i oličena, i to prije formiranja stubišnog rizalita u današnjoj visini. Vidi: PETAR PUHMAJER - KRASANKA MAJER JURIŠIĆ IVAN BRAUT (bilj. 2), 123.

64

Na samu rizalitu utvrđen je zazidani prozor na istočnom pročelju, koji je osvjetljavao odmorište stubišta u prvom katu, a nalazio se točno u osi istovjetnog prozora na drugom katu. 
Summary

\author{
Petar Puhmajer \\ Krasanka Majer Jurišić
}

\title{
Old Town Hall in Rijeka: History of the City Council Seat from the Earliest Records to the $19^{\text {th }}$ Century
}

The authors analyse the archival sources regarding the history of the building located in Kobler Square in Rijeka, which was used as a town hall from the $16^{\text {th }}$ to $19^{\text {th }}$ centuries. It was originally built as a residential house and then repurposed for town hall in 1532. Over the course of the centuries, it underwent numerous changes. The most significant one was undertaken from 1740 to 1745 by architect Antonio Verneda, who had the second floor added, adjoined the neighbouring house, and redesigned the façades in the baroque style. The building was damaged in the earthquake of 1750, after which it was restored several times. In the late $18^{\text {th }}$ century, some of its rooms were used for different social and public events. In 1833, the city council moved out to the former Augustine monastery, and the building was converted to stores and apartments. Being located on the intersection of main streets and the central square, Rijeka's Old Town Hall has urbanistic relevance. The paper also discusses the results of conservation research conducted on the building, which enabled distinguishing of the construction phases.

Keywords: architecture, $16^{\text {th }}$ century, $18^{\text {th }}$ century, baroque architecture, Rijeka, town hall, loggia, Antonio de Verneda, construction history 


\section{Izvori ilustracija i autori fotografija / Sources of illustrations and photo Credits}

\begin{abstract}
Laura Chinellato
Le lastre longobarde del »pulpito di Maviorano« di Gussago (Brescia): dall' analisi al contesto. Problematicità e nuove prospettive / Langobardske ploče "Mavioranove propovjedaonice « u Gussagu (Brescia): od analize do konteksta. Problematika i nove perspektive

1: Elaborazione grafica di Laura Chinellato da: Paola Marina De Marchi, Calvisano e la necropoli d' ambito longobardo in località Santi di Sopra. La pianura tra l'Oglio, Mella e Chiese nell'altomedioevo, in: L'Italia centro-settentrionale in età longobarda, Atti del Convegno (Ascoli Piceno, 6-7 ottobre 1995), (a cura di) Lidia Paroli, Firenze, 1997., 377-411, fig. 2 / Ilustraciju iz članka: Paola Marina De Marchi, Calvisano e la necropoli d' ambito longobardo in località Santi di Sopra. La pianura tra l'Oglio, Mella e Chiese nell'altomedioevo, in: L'Italia centro-settentrionale in età longobarda, Atti del Convegno (Ascoli Piceno, 6-7 ottobre 1995), (a cura di) Lidia Paroli, Firenze, 1997., 377-411, 2, grafički obradila Laura Chinellato.

2: Studio Rapuzzi di Brescia

3, 4, 5, 6, 7, 8, 10: Laura Chinellato

9: Bruno Genito, Sasanidi, u: Enciclopedia dell'Arte Medievale, X, Roma, 1999., 381-386.
\end{abstract}

\section{Danko Zelić - Ivan Viđen}

Inventario dela giexia di S. Maria Mazor, de tute le argentarie, aparati deli sazerdoti, insenarii, libri, tapezarie et altre robe (1531.) - najstariji imovnik liturgijske opreme, ruha i paramenata dubrovačke prvostolnice / Inventario dela giexia di S. Maria Mazor, de tute le argentarie, aparati deli sazerdoti, insenarii, libri, tapezarie et altre robe (1531) - the Oldest Extant Inventory of Liturgical Objects, Vestments and Textiles of Dubrovnik Cathedral

1: Danko Zelić

2, 3: Božo Gjukić

\section{Josipa Alviž}

Sudbina kapucina i kapucinskoga hospicija u Herceg Novom u svjetlu novih arhivskih istraživanja / The Capuchins and their Hospice in Herceg Novi in the Light of Recent Archival Research

1, 2: Državni arhiv u Zadru (DAZD) / State Archives in Zadar 3, 5, 6, 8-10, 12: Josipa Alviž

4, 7, 11: Arhitektonski crteži prema nacrtima Direkcije za urbanizam Herceg Novi, urbanistički projekt Stari Grad - Herceg Novi, 1982., voditelj Boris Ilijanić, dipl. ing. arh. Izvor: Državni arhiv Crne Gore - Arhivski odsjek Herceg Novi, za tisak pripremio Ratko Horvat I Architectural drawings made after recording of the Directorate for Urban Planning Herceg Novi, Stari Grad - Herceg Novi urban development project, 1982, project leader Boris Ilijanić, architect. Source: State Archives of Montenegro - Archival Department Herceg Novi, prepared by Ratko Horvat

\section{Bojan Goja}

Kuća Dragičević: prilog poznavanju stambenih kuća u Zadru u 18. stoljeću / The Dragičević House: A Contribution to the Research on the $18^{\text {th }}$-century Houses in Zadar

\section{1-9: Bojan Goja \\ 10: Google Earth}

\section{Petar Puhmajer - Krasanka Majer Jurišić}

Stara gradska vijećnica u Rijeci: povijest sjedišta gradske vlasti od najranijih zapisa do 19. stoljeća / Old Town Hall in Rijeka: History of the City Council Seat from the Earliest Records to the $19^{\text {th }}$ Century

1, 11, 12, 13: Natalija Vasić, Hrvatski restauratorski zavod

2: Silvino Gigante, Storia del comune di Fiume, Fiume, 1913.

3: Österreichische Nationalbibliothek, Cod. 8607, fol. 3r, Fiume 4: Österreichisches Staatsarchiv, Kriegsarchiv, Kartensammlung, sign. AT-OeStA/KA KPS KS G I h,171

5: Matthäus Merian: Topographia provinciae Austriacarum, izdanje 1679.

6: Österreichisches Staatsarchiv, Kriegsarchiv, Kartensammlung, sign. AT-OeStA/KA KPS KS G I h, 175

7a, 7b: Državni arhiv u Rijeci, Gradski magistrat Rijeka, Izdvojeni nacrti, kut. 284

8: Državni arhiv u Rijeci, Tehnički ured grada Rijeke, kut. 161

9: Konzervatorski odjel u Rijeci, fototeka

10, 14: Izradili Petar Puhmajer i Marin Čalušić, Hrvatski restauratorski zavod, 2017.

\section{Sanja Cvetnić}

Dva portreta Beatrice Frankapan (?): rod i red / Two Portraits of Beatrice Frankapan (?): the Family and the Order

1: Ivan Kukuljević Sakcinski, Beatrica Frankapan i njezin rod. Zagreb [s. e. Tiskom Dioničke tiskare], 1885.

2: Adolf Bayer, Markgraf Georg und Beatrix von Frangepan: Georg des Frommen Jugend und erste Ehe, Gesellschaft für Fränkische Geschichte, u: Neujahrsblätter der Gesellschaft für Fränkische Geschichte, Ansbach: Brügel, 19 (1934.)

3: (C) Madrid, Museo Thyssen-Bornemisza

4: () Graz, Universalmuseum Joanneum Schloss Eggenberg \& Alte Galerie

5, 6: ๑ Zagreb, Hrvatski državni arhiv

7: ( ) Klagenfurt, Landesmuseum Kärnten

8: Anton Fritz, Das große Hemma-Buch, 1980.

\section{Júlia Tátrai}

Wiener Hofkünstler und die Zrínyis. Porträts in der Lobkowicz-Sammlung / Bečki dvorski umjetnici i Zrinski. Portreti u Zbirci Lobkowicz 
1: 도 Nelahozeves, Lobkowicz Sammlung, Schloss Nelahozeves / Bridgeman Images

2, 3: () Budapest, Magyar Nemzeti Múzeum (Ungarisches Nationalmuseum)

4: ( ) Trakošćan, Dvorac Trakošćan (Schloss Trakošćan)

5: (C) Nelahozeves, Lobkowicz Sammlung, Schloss Nelahozeves / Bridgeman Images

6: @ Budapest, Magyar Nemzeti Galéria (Ungarische Nationalgalerie)

7: @ Zagreb, Hrvatski državni arhiv (Kroatisches Staatsarchiv)

8: () Nelahozeves, Lobkowicz Sammlung, Schloss Nelahozeves /

Bridgeman Images

9: () Privatbesitz Familie Herberstein

10: () Wien, Kunsthistorisches Museum, Wien

11: () Prag, Lobkowicz Sammlung, Prag / Bridgeman Images

12: ๑ Budapest, Magyar Nemzeti Galéria (Ungarische Nationalgalerie)

\section{Daniel Premerl}

Ivan Tomko Mrnavić and his Coat of Arms: Self-presentation of an Illyrian Noble / Ivan Tomko Mrnavić i njegov grb: samopredstavljanje jednoga ilirskoga plemića

1, 2: Paolo Mofardin, Institute of Art History, Zagreb; Courtesy of the Metropolitan Library, Zagreb / Institut za povijest umjetnosti, Zagreb; Uz dopuštenje Metropolitanske knjižnice, Zagreb

$3,6,14,15,16,17$ : Courtesy of the National and University Library, Zagreb / Uz dopuštenje Nacionalne i sveučilišne knjižnice, Zagreb

4, 5: Paolo Mofardin, Institute of Art History, Zagreb; Courtesy of the Library of the Croatian Academy of Sciences and Arts / Institut za povijest umjetnosti, Zagreb; Uz dopuštenje Knjižnice Hrvatske akademije znanosti i umjetnosti

7, 8: Courtesy of the Research Library Zadar / Uz dopuštenje Znanstvene knjižnice Zadar

9: Fra Stipe Nosić, the Library of the Franciscan Monastery, Dubrovnik / Knjižnica Male braće, Dubrovnik

10: Tomislav Pavičić, City Museum Šibenik / Tomislav Pavičić, Muzej Grada Šibenika

11, 12: Paolo Mofardin, Institute of Art History, Zagreb; Courtesy of the Archdiocesan Archives, Zagreb / Institut za povijest umjetnosti, Zagreb; Uz dopuštenje Nadbiskupijskog arhiva, Zagreb

13: Courtesy of the Archives of the Croatian Academy of Sciences and Arts, Zagreb / Uz dopuštenje Arhiva Hrvatske akademije znanosti i umjetnosti, Zagreb

\section{Ivana Čapeta Rakić}

Ponzonijevih deset slika u svodu glavnog oltara splitske katedrale: razmatranja o stilsko-oblikovnim svojstvima, izvornoj funkciji i ikono- grafsko-ikonološkom aspektu / Ten Paintings by Matteo Ponzoni above the Main Altar of the Split Cathedral: Considerations on Design and Style, the Original Function, and the Iconographic-Iconological Aspect

\section{1, 2: Ivana Čapeta Rakić}

3: Ivana Čapeta Rakić, rekonstrukcija / reconstruction: Vojan Koceić 4: Mirko Pivčević, rekonstrukcija / reconstruction: Vojan Koceić

5: Uz dopuštenje Fondazione Musei Civici di Venezia / Courtesy of the Fondazione Musei Civici di Venezia

6: Fotografija preuzeta sa službene web stranice muzeja www.museunacional.cat, uz dopuštenje za preuzimanje i objavu fotografije od muzeja Museu Nacional d'Art de Catalunya / Photo from the official website of the museum, www.museunacional.cat (courtesy of the Museu Nacional d'Art de Catalunya)

\section{Renata Komič Marn}

Saint Joseph and Baby Jesus by Valentin Metzinger and Other Paintings from the Strahl Collection in the Museum of Arts and Crafts in Zagreb / Slika Sveti Josip s malim Isusom Valentina Metzingera $i$ druge slike iz Zbirke Strahl u Muzeju za umjetnost i obrt u Zagrebu

1, 3-6: Srećko Budek i Vedran Benović, Muzej za umjetnost i obrt / Museum of Arts and Crafts, Zagreb, digitalne snimke predmeta iz muzejskog fundusa

2: Ljudevit Griesbach, HAZU, Strossmayerova galerija starih majstora, Zagreb / Croatian Academy of Sciences and Arts, Strossmayer Gallery of Old Masters, Zagreb

\section{Jasminka Najcer Sabljak}

Prizori iz Slavonije i Srijema u opusu austrijskog slikara Franza Alta I Scenes from Slavonia and Syrmia in the Opus of Austrian Painter Franz Alt

\section{1, 9: Georg Eltz}

2, 4-8: Francisca Clary-Aldringen

3: Arhiv Zavičajnog muzeja Ruma / Archive of the Ruma County Museum

\section{Ana Šeparović}

Od »sinteze likovnih umjetnosti« do Zagrebačkoga salona: prilog poznavanju djelovanja ULUH-a 1960-ih / From a "Synthesis of Visual Arts" to the Zagreb Salon: A Contribution to the Research on ULUH's Activity in the 1960s

1: Socijalizam i modernost, katalog izložbe, Zagreb, 2012., 141. 